\title{
NOTE
}

\section{DEFAMATION, PRIVACY AND THE FIRST AMENDMENT}

For the past dozen years, the Supreme Court has sought to reconcile the interests of state libel laws with the values of the first amendment." The balance has been a delicate one, for "libel remains premised on the content of speech and limits the freedom of the publisher to express certain sentiments. . . ."2 In Gertz v. Robert Welch, Inc., ${ }^{3}$ the Court attempted to achieve this balance by eliminating the doctrine of strict liability in defamation cases ${ }^{4}$ and by imposing a requirement that actual injuries be separately alleged and proved as a predicate to the recovery of damages. ${ }^{5}$ Because these holdings substantially modified the common law of defamation, ${ }^{6}$ it was not immediately clear how the changes were to be applied. ${ }^{7}$

THE FOLLOWING CITATIONS WILL BE USED IN THIS NOTE:

1 F. HARPER \& F. JAMES, THE LAW OF TORTS (1956) [hereinafter cited as F. HARPER \& F. JAMES];

M. Newell, The LaW of LIbel and Slander (2d ed. 1898) [hereinafter cited as M. NEWELL];

W. Prosser, Handbook of the LAW of ToRTs (4th ed. 1971) [hereinafter cited as W. ProssER];

RESTATEMENT (SECOND) of ToRTs [hereinafter cited as Restatement];

Warren \& Brandeis, The Right to Privacy, 4 HARV. L. REv. 193 (1890) [hereinafter cited as Warren \& Brandeis].

1. See note 14 infra and text accompanying notes $41-48$ infra. The seminal case in this area is New York Times Co. v. Sullivan, 376 U.S. 254 (1964).

2. Curtis Publishing Co. v. Butts, 388 U.S. 130, 152 (1967) (opimion of Harlan, J., announcing the judgment of the Court).

3. 418 U.S. 323 (1974).

4. Id. at 347. See notes 50-52 infra and accompanying text.

5. 418 U.S. at 349 . See text accompanying notes 53-62 infra.

6. The common law presumed harm to reputation and mental comfort from the mere utterance of a defamatory falsehood. See note 30 infra and text accompanying notes 28-31 infra. A publisher of a defamatory falsehood was held strictly liable for the consequences of his act. See note 50 infra. The Court's holdings in Gertz, therefore, significantly altered the common law. Mr. Justice White found this action disturbing: "[Y]ielding to the apparently irresistible impulse to announce a new and different interpretation of the First Ameudment, the Court discards history and precedent in its rush to refashion defamation law in accordance with the inclinations of a perhaps evanescent majority of the Justices." 418 U.S. at 380 (White, J., dissenting).

7. Several commentators have endeavored to make predictions concerning the future course of defamation law after Gertz. See, e.g., Anderson, Libel and Press SelfCensorship, 53 Texas L. Rev. 422 (1975); Eaton, The American Law of Defamation 
The Court's most recent decision in this area clarifies some of the ambiguities of $\mathrm{Gertz}^{8}$, but also raises the new problem of whether the Gertz rationale will be extended beyond defamation. In Time, Inc. v. Firestone, ${ }^{9}$ the Court permitted recovery for defamation solely on the basis of mental pain and anguish; no injury to reputation was alleged or proved. ${ }^{10}$ While this ruling comports with the common law's formula for danages in defamation actions, ${ }^{11}$ it also suggests that the constitutional distinctions between defamation and the tort of invasion of privacy may in the future be ignored. ${ }^{12}$

Until Firestone, the two torts differed greatly with respect to the constitutional protection afforded defendants. In Time, Inc. v. Hill, ${ }^{13}$ the Court held that plaintiffs must prove "actual malice" on the part of defendants, that is, knowledge that a statement was false or reckless disregard of whether it was false or not, ${ }^{14}$ in order to recover on claims

Through Gertz v. Robert Welcb, Inc. and Beyond: An Analytical Primer, 61 VA. L. Rev. 1349 (1975); Robertson, Defamation and the First Amendment: In Praise of Gertz v. Robert Weich, Inc., 54 TEXAs L. REv. 199 (1976); Wade, Defamation, The First Amendment and the Torts Restatement, 11 Forum 3 (1975). Moreover, the Restatement of Torts has expressed more than the usual number of caveats in this area, thus indicating the present unsettled state of defamation law. See Wade, supra, at 7.

8. Gertz left unclear both the actual damages question (which was addressed in Firestone, see notes 60-62 infra and accompanying text) and how far the Court's elimination of strict liability would extend. Strict liability traditionally appeared in defamation cases in five different contexts, and commentators have not agreed on whether Gertz should be applied in each one. See note 51 infra and authorities cited therein.

9. 424 U.S. 448 (1976).

10. Id. at 460 . See notes 60-62 infra and accompanying text.

11. At common law, defamation was defined in terms of the mere "tendency" of the words to injure reputation. Once it was established that the words had such a tendency, damages were presumed from the mere utterance of the statement, regardless of whether any actual injuries in fact resulted. See text accompanying notes 26-31 infra.

12. As for the common law distinctions between these torts, see text accompanying notes $26-40,66-81$ infra.

13. 385 U.S. 374 (1967). The case involved a magazine article reporting the opening of a new play based on the actual experiences of a family held captive by three escaped convicts. The play dealt with this subject matter in a "fictionalized" manner, but the article allegedly failed to distinguish between fiction and fact. The Supreme Court held that the actual malice standard should apply in all false light privacy cases where the reports involved "matters of public interest." Id. at 387-88. The Court cautioned, however, that

[t] his is [not] a libel action by a private individual .... Were this a libel

action, the distinction which has been suggested between the relative oppor-

tunities of the public official and the private individual to rebut defamatory

falsehoods might be germane. And the additional state interest in the protec-

tion of the individual against damage to his reputation would be involved.

Id. at $390-91$.

14. This "actual malice" standard was first established by the Court in New York Times Co. v. Sullivan, 376 U.S. 254 (1964), the seminal case in the trend toward the "constitutionalization" of common law defamation. The Court recognized "[t]hat erroneous statement is inevitable in free debate, and that it must be protected if the freedoms of expression are to have the "breathing space' that they 'need . . . to survive." " 
of false light privacy. ${ }^{15}$ This holding applies in all cases where the false reports concern "inatters of public interest," 16 and no distinction is made between so-called "public" and "private" figures. In fact, the Court explicitly ruled this distinction to be irrelevant in cases of privacy. ${ }^{17}$

In Gertz v. Robert Welch, Inc., ${ }^{18}$ however, this distinction was central to the Court's ruling. In defamation cases where plaintiff is a public figure, ${ }^{19}$ the Court stated that plaintiff is constitutionally required to show that the defendant acted with actual malice. ${ }^{20}$ Where plaintiff is a private individual, any showing of fault greater than strict liability is sufficient to overcome the initial constitutional barrier. ${ }^{21}$

Id. at 271-72. Consequently, a constitutional privilege was afforded defendants who uttered defamatory falsehoods about "public officials" in relation to their "official conduct." Id. at 279-80. It was held that a public official must prove that the defamatory statement was made "with knowledge that it was false or with reckless disregard of whether it was false or not" in order to recover. Id. This privilege was intended to erect a subjective standard, measured by whether "the defendant in fact entertained serious doubts as to the truth of his publication." St. Amant v. Thompson, 390 U.S. 727, 731 (1968) (emphasis added).

The Court expanded this privilege to cases of false light privacy in Time, Inc. v. Hill, 385 U.S. 374 (1967), and gradually broadened its application in cases of defamation. In the companion cases of Curtis Publishing Co. v. Butts and Associated Press v. Walker, 388 U.S. 130 (1967), the Court held the actual malice standard applicable in cases where the action is brought by one labeled as a "public figure." See note 122 infra for a discussion of the public figure designation. Finally, in Rosenbloom v. Metromedia, Inc., 403 U.S. 29 (1971), a plurality of the Court stretched constitutional protection to its limits and extended it "to all discussion and communication involving matters of public or general concern, without regard to whether the persons involved are famous or anonymous." Id. at 44. Since the Gertz opinion was issued in response to Rosenbloom's perceived abridgement of the state interest in protecting reputation, 418 U.S. at 346, it effectively overruled Rosenbloom. See Anderson, supra note 7, at 445.

15. For a discussion of the tort of false light privacy, see notes 32-34 infra and accompanying text.

16. 385 U.S. at $387-88$.

17. Id. at 391 .

18. 418 U.S. 323 (1974).

19. "Public figures" are those persons who have "assumed roles of especial prominence in the affairs of society." Id. at 345 . The Court recognized that it might be possible for one to become a public figure involuntarily, but "[m]ore commonly, those classed as public figures have thrust themselves to the forefront of particular public controversies in order to influence the resolution of the issues involved." Id. See text accompanying notes $121-25$ infra.

20. 418 U.S. at 342-43. In the companion cases of Curtis Publishing Co. v. Butts and Associated Press v. Walker, 388 U.S. 130 (1967), the Court had extended the constitutional privilege to public figures, and Gertz left that conclusion intact. See note 122 infra.

21. 418 U.S. at 347-48. The Court did not say what standard of proof would be required of private plaintiffs but only that "so long as they do not impose liability without fault, the States may define for themselves the appropriate standard of liability for a publisher or broadcaster of defamatory falsehood injurious to a private individual." Id. 
Thus, private plaintiffs have a higher constitutional obstacle to surmount in cases of false light privacy than in cases of defamation.

In light of the Court's recognition of the interrelationship between defamation and privacy, ${ }^{22}$ Gertz has been viewed as a threat to the continued validity of Hill as it relates to private figures. ${ }^{23}$ Firestone enlarges this threat by allowing recovery in the absence of any claim of injury to reputation. While Firestone is nominally a defamation action, the only injuries for which recovery was sought involve interests normally vindicated in privacy actions. ${ }^{24}$ Consequently, the Court's holding suggests that the Gertz principles may be extended into the privacy area: if a plaintiff can recover for mental imjuries on a showing of negligence when a false statement is defannatory, it seems to follow that the same standard should govern where similar injuries result from a non-defamatory statement. ${ }^{25}$

This Note examines the torts of defamation and privacy in an effort to determine the wisdom of such an extension in view of the values of free speech. It concludes that adequate protection of first amendment freedoms requires retention of the actual malice standard in all invasion of privacy actions irrespective of the defamatory character of the statement or of whether a public or private figure brings the action.

Since negligence is the law's least stringent standard of liability based on fault, the Court was presumably permitting the states to allow recovery on this basis. Several of the states have in fact done so. See Troman v. Wood, 62 Ill. 2d 184, 340 N.E.2d 292 (1975); Gobin v. Globe Publishing Co., 216 Kan. 223, 531 P.2d 76 (1975); Wilson v. Capital City Press, 315 So. 2d 393 (La. App. 1975); Food Fair Stores, Inc. v. Lascola, 31 Md. App. 153, 355 A.2d 757 (1976); Stone v. Essex County Newspapers, Inc., Mass. -, 330 N.E.2d 161 (1975); Thomas H. Maloney \& Sons v. E.W. Scripps Co., 43 Ohio App. 2d 105, 334 N.E.2d 494 (1974), cert. denied, 423 U.S. 883 (1975); Martin v. Griffin Television, Inc., 549 P.2d 85 (Okla. 1976). Other states, however, have retained the "actual malice" standard established by previous Supreme Court cases. See Walker v. Colorado Springs Sun, Inc., - Colo. - 538 P.2d 450 (1975); Aafco Heating and Air Conditioning Co. v. Northwest Publishing Co., - Ind. App. -, 321 N.E.2d 580 (1974); Safarets, Inc. v. Gannett Co., 80 Misc. 2d 109, 361 N.Y.S.2d 276 (Sup. Ct. 1974).

22. The rationale for the Court's decision in Time, Inc. v. Hill, 385 U.S. 374 (1967), was derived from the defamation cases it had already decided. See id. at 38890. The Court did caution, however, that "although the First Amendment principles pronounced in New York Times guide our conclusion, we reach that conclusion only by applying these principles in this discrete context." Id. at 390-91.

23. See Restatement $\S 652 \mathrm{E}$, comment d, at 35 (Tent. Draft No. 22, 1976). See also Wade, supra note 7, at 13-14. In Cantrell v. Forest City Publishing Co., 419 U.S. 245, 250-51 (1974), decided shortly after Gertz, the Court expressly left this issue open.

24. See note 32 infra.

25. Cf. W. Prosser $\$ 117$, at $817-18$ (privileges which apply in defamation should also apply in cases of privacy); Warren \& Brandeis at 216-17. 
Accordingly, the Court will be faced with a dilemma when it considers a privacy action brought by a non-public figure: Firestone must either be distinguished or limited. It is contended here that the second alternative is the more feasible solution.

The Note will begin by discussing the way in which the Supreme Court's recent decisions have altered the common law of defamation and privacy to take fuller account of the public's interest im free speech. It will then analyze more closely the various interests protected by defamation and privacy actions in order to determine whether the Court's potential merger of these two torts would adequately accommodate those interests. That section will also examine the common law's general approach to damages for mental injuries and will consider defamation and privacy in this context. Fimally, the Note will discuss the effect of Firestone on privacy law and evaluate the alternative approaches the Court might take in future cases.

\section{Compensable Injuries and Damages}

\section{A. Common Law}

Defamation actions have traditionally been viewed as redressing an individual's interest in his good name and reputation. ${ }^{26} \mathrm{~A}$ communication was defamatory at common law "if it tend[ed] so to harm the reputation of another as to lower him in the estimation of the community or to deter third persons from associating or dealing with him."27 As this definition makes evident, it was unnecessary to slow

26. See F. Harper \& F. James $\S 5.1$; W. Prosser $\S 111$; Restatement $\S 559$ (Tent. Draft No. 20, 1974). Courts have often permitted recovery for injury in the form of mental suffering as well, but have considered the mental injury to be ancillary to the damage to reputation. See, e.g., Fuqua Television, Inc. v. Fleming, $134 \mathrm{Ga}$. App. 731, 215 S.E.2d 694 (1975); McMullen v. Corkum, 143 Me. 47, 54 A.2d 753 (1947); Farrar v. Tribune Publishing Co., 57 Wash. 2d 549, 358 P.2d 792 (1961). But see Kelly v. Loew's, Inc., 76 F. Supp. 473 (D. Mass. 1948). See generally RestateMENT $\$ 623$ (Tent. Draft No. 20, 1974); Day, Mental Suffering as an Element of Damages in Defamation Cases, 15 Clev.-Mar. L. Rev. 26 (1966). See notes 88-89 infra and accompanying text.

27. Restatement $\$ 559$ (Tent. Draft No. 20, 1974). See also Bordoni v. New York Times Co., 400 F. Supp. 1223 (S.D.N.Y. 1975); Gregory v. McDonnell Douglas Corp., 55 Cal. App. 3d 605, 127 Cal. Rptr. 825 (1976); Corabi v. Curtis Publishing Co., 441 Pa. 432, 273 A.2d 899 (1971). Prosser defines defamation as

that which tends to injure "reputation" in the popular sense; to diminish the esteem, respect, goodwill or confidence in which the plaintiff is held, or to excite adverse, derogatory or unpleasant feelings or opinions against him. It necessarily, however, involves the idea of disgrace. W. ProSSER \$ 111, at 739.

Liability cannot be imposed in a defamation action unless reputation is harmed in the cyes of a substantial number of persons in the community. See, e.g., Peck v. Tribune Co., 214 U.S. 185 (1909); Oberman v. Dun \& Bradstreet, Inc., 460 F.2d 1381 (7th Cir. 
actual harm to reputation in order for the communication to be defamatory. ${ }^{28}$ Once the defamatory character of the words was established, ${ }^{29}$ general damages were presumed as a result of the natural tendency of the words to do harm to reputation. ${ }^{30}$ These general damages in-

1972); Baird v. Dun \& Bradstreet, Inc., 446 Pa. 266, 285 A.2d 166 (1971). See also W. PROSSER $\$ 111$, at 743-44; Restatement $\$ 559$, comment e at 8 (Tent. Draft No. 20,1974 ). It is unnecessary, however, that most members of the community should have a lesser regard for the victim: "Liability is not a question of a majority vote." Peck v. Tribune Co., 214 U.S. at 190 (Holmes, J.).

28. See, e.g., Corabi v. Curtis Publishing Co., 441 Pa. 432, 273 A.2d 899 (1971). At common law, the difficulty of proving injury to reputation was obviated by the doctrine which presumed damages from the mere utterance of the defamatory falsehood. See note 30 infra. Evidence that no actual damage was suffered was admissible only to mitigate the amount of damages recovered. See, e.g., First Nat'l Bank v. N.R. McFall \& Co., 144 Ark. 149, 222 S.W. 40 (1920).

29. Words may be defamatory on their face, or extrinsic facts may be necessary to make out the defamatory meaning. Where words were defamatory on their face, the action was sometimes known as defamation per se. At common law, this phrase also referred to actions in which there was no requirement to plead "special damage," see note 31 infra, in order to maintain the action. These meanings were often confused with one another. For a brief discussion of this problem, see W. PROsSER $\S 112$, at 763-64. The American Law Institute has adopted the latter definition throughout the Restatement, see Restatement $\$ 569$, comment b at 55-56 (Tent. Draft No. 20, 1974), and this Note will do the same.

As a general rule, imputations that the plaintiff had committed a crime or was afflicted with a "loathesome" disease, words that defamed a person in his business, trade, profession or office, and imputations of unchastity were all actionable per se in cases of slander. See, e.g., Munafo v. Helfland, 140 F. Supp. 234 (S.D.N.Y. 1956) ("a known criminal"); Le Moine v. Spicer, 146 Fla. 758, 1 So. 2d 730 (1941) (habitual drunkenness); Barry v. Baugh, 111 Ga. App. 813, 143 S.E.2d 489 (1965) ("crazy"); Cobb v. Tinsely, $195 \mathrm{Ky} .781,243$ S.W. 1009 (1922) (bed wetting); Foley v. Hoffman, $188 \mathrm{Md}$. 273, 52 A.2d 476 (1947) (accusation of incapacity for office); Gnapinsky v. Goldyn, 23 N.J. 243, 128 A.2d 697 (1952) (imputation of unchastity). See generally F. HARPER \& F. JAMES $\$ \S 5.10-.13$; M. Newell at 93-100; W. Prosser $\$ 112$, at $754-60$ and cases cited therein; RESTATEMENT $\$ \$ 570-74$ and cases cited therein. Libel was always actionable per se when the words were defamatory on their face. See, e.g., Couper v. Vannier, 20 Ill. App. 499, 156 N.E.2d 761 (1959) (charge of "mental illness"); Brauer v. Globe Newspaper Co., 351 Mass. 53, 217 N.E.2d 736 (1966) ("mentally retarded"). Until recently, however, the majority of American courts have held that when extrinsic facts are necessary to make out the defamatory meaning of the statement, special damages must also be proved in order to maintain the action, unless the statement falls into one of the exceptional categories of slander. See, e.g., cases cited in W. Prosser $\S 112$, at 763 nn.32-33. See generally Prosser, Libel Per Quod, 46 VA. L. Rev. 839 (1960). The recent trend of the law, however, has been to hold all libel actionable per se. See, e.g., Hinsdale v. Orange County Publishers, 17 N.Y.2d 284, 217 N.E.2d 650 (1966); Hinkle v. Alexander, 244 Ore. 267, 417 P.2d 586 (1966); Pitts v. Spokane Chronicle Co., 63 Wash. 2d 763, 388 P.2d 976 (1964); Martin v. Outboard Marine Corp., 15 Wisc. 2d 452, 113 N.W.2d 135 (1962). See also Restatement $\S 569$ (Tent. Draft No. 20, 1974).

30. The basis for the common law doctrine of presumed damages is that

[a]ctual damage to reputation may be suffered [but] the plaintiff may be unable to prove it. By the very nature of the harm resulting from defamatory publications, it is frequently not susceptible of objective proof. Libel and 
cluded compensation for injury to reputation as well as for any mental suffering which resulted from the defaination. ${ }^{31}$

Recovery for invasion of privacy, by contrast, redresses an imdividual directly for mjuries to his sensibilities resulting from unwarranted intrusions or publicity. ${ }^{32}$ When the publicity includes inaccu-

slander work their evil in ways that are invidious and subtle. The door of opportunity may be closed to the victim without his knowledge, his business or professional career limited by the operation of forces which he cannot identify but which, nonetheless, were set in motion by the defamatory statements.

F. HARPER \& F. JAMES § 5.30. See also Gertz v. Robert Welch, Inc., 418 U.S. 323, $392-95$ (1974) (White, J., dissenting). An additional problem is that "the only witnesses able to establish the necessary causal connection [between harm resulting from injury to reputation and the defamatory utterance] may be reluctant to testify that the publication affected their relationships with the plaintiffs." Note, Developments in the Law-Defamation, 69 HARv. L. REv. 875, $891-92$ (1956). Thus, the common law presumed damages from the mere utterance of the defamatory falsehood, and publishers of the defamation were held strictly liable for their conduct regardless of whether or not they might have reasonably known or expected the statement to be defamatory. See note 50 infra.

Several factors were considered by the jury in assessing presumed damages. These included the area of dissemination, the previous reputation of the plaintiff, whether and in what spirit a retraction was issued by the defendant, and evidence of aversion, contempt or social ostracism. See F. HARPER \& F. JAMES $\$ 5.30$.

31. "General damages are those which the law will presume to be the natural or probable consequences of the defamatory words. . ." M. NEWELL at 838 . Thus, general damages are intended to compensate the plaintiff for the injury done to his reputation and for any mental distress he may have suffered. See id. at 841; RESTATEMENT $\$ 621$, comment a at 78-79 (Tent. Draft No. 21, 1975). They are to be distinguished from special damages.

Special damages compensate for injuries which are not inferred from the nature of the words themselves, but must be specifically alleged and proved. See M. NEWELL at $849 ;$ W. Prosser $\$ 112$, at 760 . Furthermore, they must be derived from the loss of an asset of measurable value. See F. HARPER \& F. JAMES $\& 5.30$; M. Newell at 851, 856-57; W. Prosser $\$ 112$, at 760-61. Thus, a difficulty arises for plaintiff because certain defamation actions are maintainable only if special damages are proved. See note 29 supra. Moreover, the law has consistently refused to recognize mental suffering as a special damage sufficient to confer a right of action. See, e.g., Clark v. Morrison, 80 Ore. 240, 156 P. 429 (1916). See generally Day, supra note 26. Compensation for mental suffering may be included as an element of general damages, however, once the cause of action is established. F. HARPER \& F. JAMES $\$ 5.30$; W. Prosser $\$ 112$, at 761.

32. See text accompanying notes 70-78 infra. Modern jurisprudence has identified four torts under the rubric of invasion of privacy: "unreasonable intrusion upon the seclusion of another," see RestatemENT $\$$ 652B (Tent. Draft No. 22, 1976); "appropriation of the other's name or likeness," see id. $\$ 652 \mathrm{C}$; "unreasonable publicity given to the other's private life," see id. $\$ 652 \mathrm{D}$; and "publicity which unreasonably places the other in a false light before the public," see id. $\$ 652 \mathrm{E}$.

The first category of privacy involves intentional interference with an individual's interest in seclusion or solitude, whether the intrusion be by physical means or otherwise. See, e.g., Walker v. Whittle, 83 Ga. App. 445, 64 S.E.2d 87 (1951) (entry without legal authority to make arrest); Souder v. Pendleton Detectives, 88 So. $2 \mathrm{~d} 716$ (La. App. 1956) (spying into windows); Welsh v. Pritchard, 125 Mont. 517, 241 P.2d 816 (1952) 
rate statements of fact, the tort is known as "false light" invasion of privacy, that is, publicity which displays the individual other than as he actually is. ${ }^{33}$ It is this branch of privacy which most closely resembles

(landlord moving in on tenant); Sutherland v. Kroger Co., 110 S.E.2d 716 (W. Va. 1959) (illegal search of woman's shopping bag in store). See also RESTATEMENT $\S 652 B$ (Tent. Draft No. 22, 1976). The action has clear elements of trespass. See Prosser, Privacy, 48 Calif. L. Rev. 383, 389-90 (1960).

The second category, appropriation, involves what has become known as the "right of publicity," that is, the right of one to exploit commercially his own name or likeness and to seek compensation from anyone else who attempts to exploit them. See, e.g., Haelan Labs, Inc. v. Topps Chewing Gum, Inc., 202 F.2d 866 (2d Cir.), cert. denied, 346 U.S. 816 (1953); Pallas v. Crowley, Milner \& Co., 322 Mich. 411, 33 N.W.2d 911 (1948). See generally Restatement § 652C (Tent. Draft No. 22, 1976); Prosser, Privacy, supra, at 401-07. One commentator has suggested that the right is a separately cognizable legal interest and that privacy actions inadequately vindicate this interest. Nimmer, The Right of Publicity, 19 LAW \& CONTEMP. Prob. 203 (1954).

The third category, publicity given to private life, is the form most commonly identified with the right of privacy. The earliest supporters of a right to privacy contemplated that this form, together with false light privacy, infra, would operate as the primary means of protection. See Warren \& Brandeis. In order to succeed in his suit, a plaintiff must prove that the publicized facts would be offensive or objectionable to a reasonable man of ordinary sensibilities. See, e.g., Gill v. Hearst Publishing Co., 40 Cal. 2d 224, 253 P.2d 441 (1953); Meetze v. Associated Press, 230 S.C. 330, 95 S.E.2d 606 (1956). See generally Restatement $\&$ 652D, comment $c$ at 23-24 (Tent. Draft No. 22, 1976). During most of the twentieth century, however, this third category has been successfully employed in very few cases, primarily because of increasing judicial recognition of a "newsworthiness" privilege. See note 77 infra. It has been suggested that only privacy protected by the Constitution-for example, the privacy of one's sexual habits or marital behavior, see, e.g., Roe v. Wade, 410 U.S. 113 (1973) (woman's private right to decide whether to continue pregnancy); Griswold v. Connecticut, 381 U.S. 479 (1965) (married couple's private right to decide to use contraceptives) - should be protected by this third form of privacy action. See T. EMERSON, THE SYSTEM OF FREEDOM OF EXPRESSION 555-57 (1970). See also Wade, supra note 7, at 14.

The final category of privacy, known as false light privacy, involves injuries resulting from publicity which places one in a "false light" in the public eye by conveying erroneous or misleading information about the individual. See note 33 infra and cases cited therein. This tort has also been described as "nondefamatory falsehood," see Pember \& Teeter, Privacy and the Press Since Time, Inc. v. Hill, 50 WASH. L. Rev. 57, 8387 (1974), because its sole distinction from defamation is that the false or misleading publicity has no tendency to injure reputation. The falsehood very often proves to be defamatory, however, in which case both actions will lie. See, e.g., W. Prosser \$ 117 , at 813 n.19 and cases cited therein. See also Restatement $\S 652 \mathrm{E}$, comment $\mathrm{b}$ at $31-32$ (Tent. Draft No. 22, 1976). Because of their great similarity, it has been suggested that defamation and false light privacy should be condensed into a single tort. See W. Prosser $\S 117$, at 813-14; Wade, Defamation and the Right of Privacy, 15 VAND. L. REv. 1093 (1962). Contrast the argument made in the text accompanying notes 126-37 infra. It should be noted that this division of the right of privacy into four separate groupings has not met with universal approval. See, e.g., Kalven, Privacy in Tort LawWere Warren and Brandeis Wrong?, 31 LAW \& CoNTeMP. Prob. 326, 332-33 (1966); Bloustein, Privacy as an Aspect of Human Dignity: An Answer to Dean Prosser, 39 N.Y.U. L. REV. 962 (1964).

33. See, e.g., Cantrell v. Forest City Publishing Co., 419 U.S. 245 (1974) (inaccu- 


\section{defamation, since both are predicated upon false statements of fact. ${ }^{34}$}

Invasion of privacy is a recent invention of the common law..$^{35}$ The action as originally conceived was designed to provide redress for "wounded feelings" resulting from publicity given to private affairs. ${ }^{36}$ To the extent that both privacy and defamation actions are intended to compensate plaintiffs for mental disturbance, the two torts overlap. ${ }^{37}$ Nevertheless, they are not entirely interchangeable. A statement can be defamatory but not concern private affairs. Conversely, publicity may be given to private affairs yet include no defamatory statements.

rate report of family's life style after death of father); Time, Inc. v. Hill, 385 U.S. 374 (1967) (article misstating facts of family's encounter with escaped criminals); Varnish v. Best Medium Publishing Co., 405 F.2d 608 (2d Cir. 1968), cert. denied, 394 U.S. 987 (1969) (false account that suicide victim's life was "happy"); Steding v. Battistoni, 3 Conn. Cir. Ct. 76, 208 A.2d 559 (1964) (filing suit in plaintiff's name without authorization); Hinish v. Meier \& Frank Co., 166 Ore. 482, 113 P.2d 438 (1941) (imposturous use of telegram to governor urging him to veto bill). See generally W. PROSSER $\S 117$, at 812-14; RestatemENT $\S 652$ E (Tent. Draft No. 22, 1976); Prosser, supra note 32, at 398-401. For the purposes of this Note, whenever "privacy" is used, the reference will be to "false light" privacy, unless the context clearly shows otherwise.

34. It has been questioned "whether this branch of the tort is not capable of swallowing up and engulfing the whole law of defamation; and whether there is any false libel printed, for example, in a newspaper, which cannot be redressed upon the alternative ground." W. ProsSER $\$ 117$, at 813 . This argument has also been made by Dean Prosser's successor as Reporter to the Restatement of Torts. See Wade, supra note 32.

While the resemblance between the torts is admittedly great, significant differences do exist. For example, defamation requires that there be a "publication," a term of art which includes private communication, while privacy requires public communication. See RESTATEMENT § 652D, comment a, at 21 (Tent. Draft No. 22, 1976). Most actions in slander, that is, oral defamation, see W. PROSSER $\$ 112$, at 752-62, would therefore probably not be actionable as false light privacy. Moreover, the Supreme Court presently recognizes a higher level of constitutional protection for the media in privacy cases than in defamation cases. See text accompanying notes 13-21 supra. Finally, theoretical considerations implicit in tort law also provide reasons for separate treatment of the torts. See text accompanying notes 126-43 infra.

35. See text accompanying notes $70-78$ infra. The first case that explicitly recognized a right of privacy was decided in 1890 and was followed by a series of other lower court decisions. See discussion in W. Prosser $\$ 117$, at 803 n.10. Pavesich v. New England Life Ins. Co., 122 Ga. 190, 50 S.E. 68 (1905) (use of plaintiff's unauthorized picture with spurious testimonial), was the first case in which a court of last resort accepted the existence of the right. See generally W. Prosser \$ 117, at 802-04.

36. Warren and Brandeis recognized that "a legal remedy for such injury seems to involve the treatment of mere wounded feelings, as a substantive cause of action." Warren and Brandeis at 197. They were aware, however, that recovery for wounded feelings had to be attendant to a violation of a recognized legal right before it would be permitted. Id. at 197-98. Thus, they devoted their article to proving the existence of the right to privacy, see notes 70-78 infra and accompanying text, and concluded that the remedy for violation of this right would be an action in tort for damages: "Even in the absence of special damages, substantial compensation could be allowed for injury to feelings. ... ." ld. at 219.

37. See note 34 supra. 
It is only in cases where the unwanted publicity is also defamatory that either action will lie. ${ }^{38}$

If an action were maintainable on the basis of both defamation and privacy, it made little difference which was actually asserted. ${ }^{39} \mathrm{Be}-$ cause general damages in defannation actions were presumed, the coinmon law saw no need to differentiate between injury to reputation and injury to mental comfort. ${ }^{40}$ Thus, the interests protected by both torts received adequate vindication in an action brought for defamation.

\section{B. Supreme Court Modifications}

In recent years, the Supreme Court has recognized that common law privileges ${ }^{41}$ are inadequate to preserve the public's interest in free

38. See, e.g., W. Prosser $\$ 117$, at 813 n. 19 and cases cited therein. The American Law Institute also supports this position. See RESTATEMENT $\S 652 E$, comment $b$ at 31 (Tent. Draft No. 22, 1976).

39. This statement is generally true, but there are some differences involved in bringing one action or the other. For example, there is no need to prove special damages in the case of privacy, and different results obtain with respect to the applicable statute of limitations and survival of the action. See W. Prosser $\$ 117$, at 814 and cases cited therein.

40. For example, in one case the judge instructed the jury that "the appropriate measure of damages [in a libel suit] is the loss of reputation suffered by the plaintiff, the physical pain which he has suffered, and the mental anguish which he has suffered." Curley v. Curtis Publishing Co., 48 F. Supp. 29, 34 (D. Mass. 1942) (Wyzanski, J.). No attempt was made to distinguish among any of these bases for recovery, so it would be unclear from the final award which injuries were in fact compensated for. After Gertz, this type of instruction is no longer permissible.

41. The common law protects defendants with a number of absolute and qualified privileges which are available depending upon the character of the defendant or upon the circumstances of the defamation. Absolute privileges "are based chiefly upon a recognition of the necessity that certain persons, because of their special position or status, shall be free as possible from fear that their actions in that position may have an adverse effect upon their own personal interests." RESTATEMENT, Introductory Note $\S \S 585-592 \mathrm{~A}$ at 160 (Tent. Draft No. 20, 1974). Absolute immunity is extended to all parties to a judicial proceeding, including the judge, attorneys, the disputants, witnesses, and jurors, to all legislators, executive and administrative officers of the United States and the superior executive officers of the respective states, and to a husband and wife. See F. HARPER \& F. JAMEs $\$ 5.22-.23$; M. Newell at 418-75; W. Prosser $\S 114$ and cases cited therein. The continued validity of absolute immunity for federal executive and administrative officers and for state executive officers, however, is questionable in light of the Supreme Court's holding in Scheuer v. Rhodes, 416 U.S. 232 (1974), and the District of Columbia Circuit Court's decision in Apton v. Wilson, 506 F.2d 83 (D.C. Cir. 1974). It was held in Scheuer that state executive officers are protected by only a qualified immunity in actions brought under 42 U.S.C. $\$ 1983$, and $A p-$ ton extended the Scheuer rationale to such actions brought against federal executive officers. Although these cases were concerned with section 1983, their rationales might be applicable to defamation actions as well. See Economou v. Department of Agriculture, 535 F.2d 688 (2d Cir. 1976).

A new absolute privilege has developed protecting those who are required by law 
to publish matter which may be defamatory. Restatement $\$ 592 \mathrm{~A}$ (Tent. Draft No. $20,1974)$. This privilege was established by the Supreme Court with respect to radio and television broadcasts under the Federal Communications Act. See Farmers Educ. \& Coop. Union v. WDAY, Inc., 360 U.S. 525 (1959). Finally, it should be noted that the absolute privilege created by the Supreme Court for federal officers in Barr v. Matteo, 360 U.S. 564 (1959), was the basis for the Court's establishment of the actual malice standard when public officials are plaintiffs. See New York Times Co. v. Sullivan, 376 U.S. 254, 282 (1964) ("Such a privilege for criticism of official conduct is appropriately analogous to the protection accorded a public official when he is sued for libel by a private citizen").

In addition to these absolute privileges, defendants are further insulated from liability in defamation actions by various absolute defenses. An absolute defense is available where the plaintiff has given his consent to the publication, see RESTATEMENT $\$$ 583 (Tent. Draft No. 20, 1974), or where the defamatory utterance is true, see W. Prosser $\S 116$, at 796-99 and cases cited therein; Restatement $\$ 582$ (Tent. Draft No. 20, 1974). The question of truth as a defense has been a troublesome one for the Supreme Court. Some have thought that Gertz had settled the issue, reasoning that defendant could not be at fault if the statement were true, see Cox Broadcasting Corp. v. Cohn, 420 U.S. 469, 497-500 (1975) (Powell, J., concurring); see also Wade, supra note 7, at 12, but the majority opinion in Cox expressly left this question open: "Rather than address the broader question whether truthful publications may ever be subjected to civil or criminal liability consistently with the First and Fourteenth Amendments, or to put it another way, whether the State may ever define and protect an area of privacy free from unwanted publicity in the press, it is appropriate to focus on the narrower interface between press and privacy that this case presents . . ." 420 U.S. at 491.

Qualified, or conditional, privileges are intended to "afford a protection based upon a public policy which recognizes that it is essential that true information shall be given whenever it is reasonably necessary for the protection of one's own interests, the interests of third persons, or certain interests of the public." REstatemENT, Scope Note $\S \S 593-605 \mathrm{~A}$, at 188 (Tent. Draft No. 20, 1974). A qualified privilege is available where the publisher of the falsehood is seeking to protect any lawful, pecuniary interest he possesses, see, e.g., Restatement $\$ 594$ (Tent. Draft No. 20, 1974) and cases cited therein; where the publisher seeks to protect the interest of the recipient of the information or of a third person, as, for example, where the publisher is a credit agency, a hired investigator, or a person asked to provide information about a present or prospective employee of the recipient, see, e.g., id. $\$ 595$ and cases cited therein; where the publislzer has a common interest with the recipient, for example, where they are both members of a religious, fraternal or charitable organization, or where they have common property or business and professional interests, see, e.g., id. $\$ 596$ and cases cited therein; where the publisher acts to serve the well-being of a member of his immediate family, see, e.g., id. $\$ 597$ and cases cited therein; where the communication is made to one who may act in the public interest, see, e.g., id. $\$ 598$ and cases cited therein; and where the publisher is an inferior state officer, see, e.g., id. $\$ 598 \mathrm{~A}$ and cases cited therein. See also F. HARPer \& F. James $\$ \S 5.25-.26$; M. Newell at 475-563; W. Prosser $§ 115$, at 785-92 and cases cited therein. Moreover, two other conditional privileges available at common law, fair comment on matters of public concern and reports of public proceedings, see F. HARPER \& F. JAMES $\$ \S 5.24,5.26$; M. NEWELL at 564-92; RESTATEMENT $\$ \$ 606-12$ (Tent. Draft No. 20,1974), have become subsumed under the constitutional privilege created by the Supreme Court, which is itself a qualified privilege that can be defeated by a showing of actual malice. See W. Prosser $\S 115$, at 792.

Conditional privileges are unavailable to a defendant if he has abused the occasion or steps outside the scope of his privilege. The privilege may be defeated because of the publisher's lack of belief or reasonable grounds for belief in the truth of the defamatory matter; because the defamatory matter is published for some purpose other than that for which the privilege is available; because the publication is made to some person not 
speech. ${ }^{42}$ Free speech has always been a "preferred freedom" in America ${ }^{43}$ and any inhibition of its exercise has been looked upon with disfavor. ${ }^{44}$ It was for this reason that the Court initiated the process of "constitutionalizing" 45 the common law of defamation and privacy. The Court feared that defamation actions might be used as a vehicle

reasonably believed to be necessary for the accomplishment of the purpose of the privilege; or because the publication includes defamatory matter not reasonably believed to be necessary for the privilege's purpose. See F. Harper \& F. JAMES $\$ 5.27$; W. Prosser $\S 115$, at 792-96 and cases cited therein; RESTATEMENT $\$ \S 599-605 a$ (Tent. Draft No. 20, 1974) and cases cited therem.

42. Indeed, in the New York Times case, the Court expressly focused its inqniry on state laws which included the cominon law privilege of "fair comment" and the defense of truth. See New York Times Co. v. Sullivan, 376 U.S. 254, 267-69 (1964).

43. In Thomas v. Collins, 323 U.S. 516 (1945), the Supreme Court noted that there is a "preferred place given in our scheme to the great, the indispensable democratic freedoms secured by the First Amendment. . . . That priority gives these liberties a sanctity and a sanction not permitting dubious intrusions." Id. at 529-30. See also Beauharnais v. Mlinois, 343 U.S. 250, 285 (1952) (Douglas, J., dissenting); Dennis v. United States, 341 U.S. 494, 581 (1951) (Black, J., dissenting); Kovacs v. Cooper, 336 U.S. 77, 88 (1949). But see id. at 90-96 (Frankfurter, J., concurring).

The preferred position of the first amendment has also been discussed by many commentators. See, e.g., McKay, The Preference for Freedom, 34 N.Y.U.L. REv. 1182, 1184 (1959) ("The central, the inescapable proposition to which this study is directed is the notion that the freedom of expression is so vital in its relationship to the objectives of the Constitution that inevitably it must stand in a preferred position.") See also T. Emerson, supra note 32; Bork, Neutral Principles and Some First Amendinent Problems, 47 Indina I.J. 1, 20-24 (1971). Judge Learned Hand stated that the first amendment "presupposes that right conclusions are more likely to be gathered out of a multitude of tongues, than through any kind of authoritative selection. To many this is, and always will be, folly; but we have staked upon it our all." United States v. Associated Press, 52 F. Supp. 362, 372 (S.D.N.Y. 1943). The New York Times case was decided "against the background of a profound national commitment to the principle that debate on public issues should be uninhibited, robust, and wide-open. . . ." New York Times Co. v. Sullivan, 376 U.S. 254, 270 (1964); cf. Gertz v. Robert Welch, Inc., 418 U.S. 323, 339-41 (1974).

44. Prior restraints upon the exercise of free speech have generally been struck down, see, e.g., New York Times Co. v. United States, 403 U.S. 713 (1971); Near v. Minnesota, 283 U.S. 697 (1931); withholding of benefits from persons for exercising their first amendment rights is generally prohibited, see, e.g., Keyishian v. Board of Regents, 385 U.S. 589 (1967) (state plan requiring employees to sign statement that they were not "Communists" as a condition for continued employment constitutionally impermissible); and even governinent action to prevent a person from advocating unlawful conduct must be predicated upon a "clear and present danger" in order to be upheld, see, e.g., Brandenburg v. Ohio, 395 U.S. 444 (1969); Whitney v. California, 274 U.S. 357, 372 (1927) (Brandeis, J., concurring).

45. Cf. Gertz v. Robert Welch, Inc., 418 U.S. 323, 370 (1974) (White, J., dissenting): "[U]sing [the First] Amendment as the chosen instrument, the Court, in a few printed pages, has federalized major aspects of libel laws by declaring unconstitutional in important respects the prevailing defamation law in all or most of the 50 states." See also Rosenbloom v. Metromedia, Inc., 403 U.S. 29, 81 (1971) (Marshall, J., dissenting). 
to suppress unpopular opinion ${ }^{46}$ and that the threat of such actions might induce publishers to exercise self-censorship to avoid the consequences of an adverse verdict. To allay these fears, the Court in a series of cases first erected and then expanded a constitutional privilege to protect defendants in most defamation actions. ${ }^{47}$ This privilege was designed to shield defendants from all liability except in those instances where they had acted with actual malice. ${ }^{48}$

In Gertz v. Robert Welch, Inc., ${ }^{49}$ the Court altered the coverage of the constitutional privilege, and also modified the common law principles regarding the element of damages in defamation actions. In sum, the Court held that actual malice need not be proved unless the plaintiff is a public figure. The Court found, however, that strict liability for defamatory utterances ${ }^{50}$ would be inconsistent with the first amendment, ${ }^{51}$ and substituted for the actual malice standard a minimal

46. See, e.g., Gertz v. Robert Welch, Inc., 418 U.S. 323, 340, 349 (1974); New York Times Co. v. Sullivan, 376 U.S. 254, 279 (1964).

47. See note 14 supra and accompanying text.

48. See note 14 supra.

49. 418 U.S. 323 (1974). The petitioner in Gertz, a Chicago lawyer, had heen engaged to represent the family of a murder victim in a civil suit against the police officer convicted of the crime. Respondent's publication, a national forum for the John Birch Society, reported on the murder conviction and alleged that it had heen engineered by the petitioner as part of a nation-wide communist campaign to discredit the police. The petitioner was labeled a "Leninist" and a "Communist-fronter" because of his purported membership in several communist organizations. Respondent's editors had made no attempt to verify these charges independently, and it was found that the statements "contained serious inaccuracies." Id. at 326.

The Seventh Circuit, holding that the article concerned issues of significant public interest, applied the New York Times standard and ruled that petitioner had failed to show actual malice on the respondent's part. Id. at 330-32. Writing for the Court, Justice Powell focused on the finding that petitioner was not a public figure and refused to apply the New York Times standard. The decision below was reversed and remanded. See id. at 332.

50. Previously, once it had been established that a statement was defamatory, it made no difference that the defendant did not intend the statement to be defamatory or that he was not otherwise negligent; he was held absolutely liable for the injury to the other. The harshness of this rule was mitigated somewhat by permitting innocent publication of the defamatory statement to a third party to go unpunished. Thus, if the defendant did not intend and could not reasonably have anticipated that a third person might hear or read the statement, there could be no liability for defamation. See W. Prosser $\$ 113$, at 772-76 and cases cited therein.

51. 418 U.S. at 347. The Court ruled that this stricture applies "[a]t least . . . where, as here, the substance of the defamatory statement 'makes substantial danger to reputation apparent.'" Id. at 348, citing Curtis Publishing Co. v. Butts, 388 U.S. 130, 155 (1967). It is unclear, however, with respect to what elements of a defamation action fault is required to be shown. There are five contexts in which the question of fault arises in a defamation action: (1) publication to a third party; (2) truth or falsity of communication; (3) defamatory character of the communication; (4) content of the communication; and (5) reference to plaintiff. See Restatement $\$ 580 \mathrm{~B}$, comment $b$ at 27 (Tent. Draft No. 21, 1975); W. Prosser $\S 113$, at 771. The common law has 
requirement that some fault on the part of the defendant be shown by private plaintiffs. ${ }^{52}$ The Court further tempered its apparent constriction of the publisher's constitutional privilege with a complementary ruling that presumed damages are no longer permissible. ${ }^{53}$ Unless the defendant published the statement with knowledge of its falsity or in reckless disregard of its truth or falsity, recovery must be limited to actual damages. ${ }^{54}$ Finally, the Court stated that actual injury "is not limited to out-of-pocket loss";"55 the plaintiff may also recover for "impairment of reputation and standing in the community, personal humiliation, and mental anguish and suffering."50 All awards, how-

never imposed strict liability in the first context. See note 50 supra. The statement in Gertz abandoning strict liability was apparently made with reference to the second context. See Restatement \$580B, comment c at 28 (Tent. Draft No. 21, 1975); Robertson, supra note 7, at 242-43. Furthermore, the statement quoted above, that the lower standard of fault is required where the "substance of the defamatory statement 'makes substantial danger to reputation apparent," " can be seen as an indication that the negligence standard is applicable in the third context as well. See Restatement $\$$ 580B, comment $c$ at 28 (Tent. Draft No. 21, 1975); Eaton, supra note 7, at 1427-28. It may well be that the logic of the Court's holding and the policy which it implements requires application of the negligence standard in all contexts. See RestatemENT $\S 580 \mathrm{~B}$, comment $c$ at 28-29 (Tent. Draft No. 21, 1975).

The response of the state courts to this problem is discussed in Anderson, supra note 7, at 461-65. The author notes that most state courts which have faced the problem since Gertz have applied the negligence standard only in the context of the truth or falsity of the statement. See note 21 supra and cases cited therein. Since Gertz effectively overruled Rosenbloom's application of the actual malice standard to all defamation cases concerning matters of public interest, see note 14 supra, and since the actual malice standard applies only with respect to the truth or falsity of the defamatory statement, the approach taken by the state courts is not surprising.

52. 418 U.S. at 347. For a discussion of what the states have done with this mandate, see note 21 supra.

53. 418 U.S. at 349-50.

54. If plaintiff could prove that defendant acted with actual malice, however, plaintiff could still recover punitive damages, and perhaps even presumed damages since the Court did not exclude this possibility. See id. See also Anderson, supra note 7, at 47377.

55. 418 U.S. at 350 . The Court was determined to avoid the appearance that its actual damage requirement corresponded to the common law concept of special damages. See, e.g., Eaton, supra note 7, at 1434-36; cf. Robertson, supra note 7, at 230-34. Special damages have to be specifically alleged and proved in order to be recovered. See note 31 supra. In this respect, they closely resemble the Gertz actual damages. In order to maintain an action upon proof of special damage, however, the injury must arise from the loss of an asset of measurable value. See notes 29,31 supra. The Court in Gertz did not wish to limit plaintiff's recovery in such a manner and expressly stated that direct pecuniary loss was not prerequisite to recovery.

56. 418 U.S. at 350. Because the Court listed all these compensable injuries together, it was unclear from the opinion whether injury to reputation was intended as a predicate to recovery for the other injuries. Many commentators have considered the case to require proof of injury to reputation before damages may be awarded for other types of injuries. See, e.g., Anderson, supra note 7, at 471-73; Eaton, supra note 7, at 1437-39. Moreover, the Restatement has added a new section which implements the Gertz actual injury requirement: "One who is liable for a defamatory communication 
ever, must be supported by "competent evidence."

The effect of Gertz is to require that all damages be alleged and proved if they are to be recovered..$^{58}$ Harm to reputation, for example, must be alleged separately from harm to mental comfort. Implicit in the imposition of the actual damages requirement was the related proposition that any form of damages, properly proved, would sustain a defamation action so long as defendant's statement was defamatory in nature. ${ }^{50}$ In Time, Inc. v. Firestone ${ }^{60}$ the Court elevated this proposition to the status of a rule of law. Plaintiff withdrew her claim of injury to reputation on the eve of trial, and relied instead solely on her claim of mental pain and anguish. ${ }^{61}$ The Court held that recovery on this basis was entirely consistent with Gertz. $^{62}$

is liable for the proved, actual harm caused to the reputation of the person defamed." Restutement \$ 621 (Tent. Draft No. 21, 1975) (emphasis added). The comments to this section further note that "general damages are imposed for the purpose of compensating the plaintiff for the harm which the publication has caused to his reputation. . . . Recovery may also be had for emotional distress and resulting bodily harm." Id., comment a, at 78 (emphasis added). See also id. $\S 623$ (Tent. Draft No. 20, 1974) (concerning damages for emotional distress).

57. 418 U.S. at 350 . Presumably, this evidence must prove both the' fact and the extent of injury, although "there need be no evidence which assigns an actual dollar value to the injury." Id. Since the determination of what is "competent evidence" is necessarily a judicial function, this requirement provides judges with great discretion to limit the ultimate disposition of the case by the jury. Moreover, the common law rule is that the judge determines what injuries are compensable and the jury merely assesses damages. See Restatement $\$ 616$ (Tent. Draft No. 20, 1974). This rule enables judges to limit jury discretion in awarding damages by withholding from the jury certain injuries. The Court seemed aware of this rule when it stated that "juries must be limited by appropriate instructions. . . ." 418 U.S. at 350.

58. This conclusion follows from the abolishment of the doctrine of presumed damages, which obviated the necessity for pleading actual damages. See, e.g., Eaton, supra note 7 , at 1434 .

59. This reading of Gertz results from the failure of the Court to distingnish between the different types of injuries to which a defamation gives rise. See 418 U.S. at 350.

60. 424 U.S. 448 (1976). Plaintiff Mary Alice Firestone was the wife of the son of one of the richest families in America. She filed for divorce, and he counterclaimed on grounds of extreme cruelty and adultery. The counterclaim was granted though the opinion was somewhat less than lucid as to the grounds for the divorce. In fact, the Suprenie Court of Florida twice considered the issue and each time arrived at a different conclusion. See id. at 478 n.8, 480 (1976) (Brennan, J., dissenting). Time magazine reported in its "Milestones" section that the divorce was granted ou the grounds set out in the husband's complaint: "The 17-month intermittent trial produced enough testimony of extramarital adventures on both sides, said the judge, 'to make Dr. Freud's hair curl.'" See id. at 452. Mrs. Firestone brought a libel action against the magazine and the jury awarded her $\$ 100,000$. The Florida Supreme Court and the United States Supreme Court both affirmed the verdict.

61. See id. at 460.

62. Petitioner's theory seems to be that the only compensable injury in a defamation action is that which may be done to one's reputation, and that 
Thus, in one sense privacy and defamation are now more distinct forms of action; in another, their overlap is emphasized more than ever before. The torts are more distinct in that one may recover for mjury to reputation and yet not recover for any accompanying mental distress unless this injury is also pleaded and proved. This result is a direct product of the interment of the doctrine of presumed damages. At the same time, however, the torts resemble one another more closely in a case like Firestone, where the only injury proved was mental distress. In such a case, the only effective distinction between the torts lies in the character of the words used by the defendant. If the words have a tendency to injure reputation, an action in defamation will lie. If the words do not have the tendency to "dimmish the esteem, respect, goodwill, or confidence in which the plamtiff is held," ${ }^{63}$ then the proper action is in privacy. Although the common law also acknowledged this overlap, ${ }^{64}$ it was not always clear in a given case whether reputation had in fact been injured, since there was no need to distinguish annong the bases for recovery. ${ }^{65}$ To the extent that this ambiguity existed, the overlap between defaination and privacy was obscured.

claims not predicated upon such injury are by definition not actions for defamation. But Florida has obviously decided to permit recovery for other injuries without regard to measuring the effect the falsehood may have had upon a plaintiff's reputation. This does not transform the action into something other than an action for defamation as that term is meant in Gertz.
Id.

Gertz suggested that the potential for harm to reputation was what earmarked an action in defamation, see Gertz v. Robert Welch, Inc., 418 U.S. 323, 348 (1974), and to this extent, the Court's statement in Firestone appears to be true. The common law's emphasis on "tendency" to injure reputation, however, arose out of the difficulties inherent in assessing damages for injured reputation, see note 30 supra, and was inextricably bound up with the doctrine of presumed damages. That the common law admitted there were difficulties of proof, however, does not alter the fact that "damage to reputation is, of course, the essence of libel." Monitor Patriot Co. v. Roy, 401 U.S. 265, 275 (1971). Moreover, in a very famous and much quoted statement, Sir Frederick Pollock commented that "The law went wrong in the beginning in making the damage and not the insult the cause of action." F. POLLOCK, THE LAW OF TORTS, 249 (13th ed. 1929), quoted in W. ProssER $\$ 111$, at 737 n.5. Gertz in no way suggests that the focus of an action in defamation has somehow been altered so that now the insult and not the injury is the cause of action. The Court's abolishment of presumed damages, therefore, necessitates the elimination of the "tendency" aspect of the definition of defamation so that the action remains the protector of the interest in reputation. See text accompanying notes 155-60 infra. See generally Anderson, supra note 7, at 472; Eaton, supra note 7, at 1437-39. As the latter article notes, "Negligent infliction of mental distress may well be a tort, but it is not the tort of defamation." Id. at 1438 .

63. W. Prosser § 111 , at 739.

64. See text accompanying notes $39-40$ supra.

65. This conclusion follows from the fact that instructions to the jury generally did not differentiate among the specific injuries which may have been incurred because all general damages were presumed. See notes 29,40 supra. 
Because Gertz has made the overlap between defamation and privacy so apparent, its logic may compel transferral of the negligence standard into the privacy area. In order to determine whether Gertz should be so extended, however, it is first necessary to analyze more closely the interests protected by actions in privacy and defamation.

\section{The Conceptual Distinctions Between Defamation and Privacy}

\section{A. Historical Origins}

From their beginnings in the early common law, defamation actions have been concerned with the protection of reputation against injury from false statements of fact. ${ }^{66}$ Reputation was seen primarily as a property right, ${ }^{67}$ though elements of "honor" were implicit in the concept. ${ }^{68}$ Moreover, stated opimions of the plaintiff were not the concern of defamation law. ${ }^{69}$ It is only where the defendant made factual

66. Reputation is the interest which defamation law is designed to protect. See note 26 supra and accompanying text. Moreover, the statement must be false, since truth is recognized at common law as an absolute defense in a civil libel action. See W. ProsSER $\S 116$, at 796-99 and cases cited therein; REstateMENT $\S 582$ (Tent. Draft No. 20, 1974) and cases cited therein. For a brief discussion of the way in which the Supreme Court has treated the defense of truth, see note 41 supra. Finally, the statement must be one of fact, not opinion. See note 69 infra. For a general discussion of the history of defamation at common law, see Holdsworth, Defamation in the Sixteenth and Seventeenth Centuries (pts. 1-3), 40 L.Q. Rev. 302 \& 397, 41 L.Q. REv. 13 (1924-25); Lovell, The "Reception" of Defamation by the Common Law, 15 VAND. L. REv. 1051 (1962); Veeder, The History and Theory of the Law of Defamation (pts. 1-2), 3 Colum. L. Rev. 546, 4 Colum. L. Rev. 33 (1903-04).

67. Warren and Brandeis thought that defamation was an inadequate instrument to protect the right of privacy because "the wrongs and correlative rights recognized by the law of slander and libel are in their nature material rather than spiritual. That branch of the law simply extends the protection surrounding physical property to certain of the conditions necessary or helpful to worldly prosperity." Warren and Brandeis at 197. It has also been recognized that the interest in reputation "so far as the law recognizes it as a proper subject for protection, is essentially one of substance." Pound, Interests of Personality, 28 HARv. L. Rev. 445, 446 (1915). Pound did acknowledge, however, that there were other less material aspects to the reputation interest. See note 68 infra.

68. Dean Pound viewed reputation as an interest of both "personality" and "substance." Pound, supra note 67, at 446-49. Defamation was intended primarily to redress the latter, $i d$. at 446 , but "[h]istorically it is quite false to treat the subject from the standpoint of a securing of interests of substance only." Id. Rather, elements of "honor," an interest of personality, were obviously part of the concept of reputation or else there are "logical anomalies from the standpoint of such a theory. . . ." Id. at 447.

69. Defamatory communications most often consist of statements of fact. See RESTATEMENT $\S 565$ (Tent. Draft No. 20,1974) and cases cited therein. The obvious reason for this pattern is that only facts are capable of being true or false. See F. HARPER \& F. JAMES $\$ 5.8$. While opinion, therefore, is almost always non-actionable as a defamatory communication, two exceptions had been carved out by the common law. Statements of opinion were actionable where the opinion was expressed on facts known 
statements about the plaintiff, and where these statements were untrue, that defamation law provided the plaintiff with a remedy.

Privacy actions, on the other hand, were originally seen as a protection against publicity, whether the statements were true or false. ${ }^{70}$ In their famous article, Warren and Brandeis observed that something akin to a right of privacy had been protected under the aegis of a number of different legal doctrines. ${ }^{71}$ They noted that defamation, ${ }^{72}$ copyright, ${ }^{73}$ and the doctrines of implied trusts and breach of confidence ${ }^{74}$ all had elements of a right of privacy in them and were sometimes used to vindicate this right. In their view, the unifying principle in all these cases was the right to choose how and in what manner one would appear before the public. ${ }^{75}$ The focus was on dignity and the

or assumed by the parties to the communication or where the opinion was expressed upon undisclosed facts. See RESTATEMENT $\$$ 566-67 (Tent. Draft No. 20, 1974) and cases cited therein. See also HARPER \& JAMES $\$ 5.8$. If, in the former case, the underlying facts were true, the expressed opinion was deemed too intimately related to the facts to be separated from them. See id. If sufficiently derogatory, the opinion was actionable. See Restatement $\$ 566$, comment a and illustration at $41-42$ (Tent. Draft No. 20, 1974). Similarly, where the underlying facts were undisclosed, it appeared that the publisher had some special knowledge upon which to base his opinion, so that the opinion implied a fact about plaintiff. See F. HARPER \& F. JAMES $\$$ 5.8; ResTATEMENT $\$ 567$, comment a and illustration at 43 (Tent. Draft No. 20, 1974). See also id. $\$$ $567 \mathrm{~A}$ and cases cited therein.

The Court in Gertz recognized the fact-opinion distinction as a matter of constitutional law, and abolished the two common law exceptions:

Under the First Amendment there is no such thing as a false idea. However pernicious an opinion may seem, we depend for its correction not on the conscience of judges and juries but on the competition of other ideas. But there

is no constitutional value in false statements of fact. 418 U.S. at 339-40.

Thus, opinion is constitutionally protected from actions for defamation under the first amendment, regardless of the form in which the opinion is expressed.

70. See note 78 infra.

71. Warren \& Brandeis at 214-19.

72. See $i d$. at 197 . The law of defamation was considered too "material," however, to provide adequate redress for the "spiritual" interests they felt the right of privacy protects. See note 67 supra. See also Kalven, supra note 32, at 328-39. Warren and Brandeis did view defamation as an acceptable analogy with reference to the limitations on the right of privacy and the appropriate remedies. See Warren \& Brandeis at 214-19.

73. "[T]he legal doctrines relating to infractions of what is ordinarily termed the common-law right to intellectual and artistic property are, it is believed, but instances and applications of a general right to privacy. . .." Warren \& Brandeis at 198. But see Kalven, supra note 32, at 329-30.

74. For example, the doctrines of implied trusts and breach of confidence were utilized to enable one whose letters were in the hands of another to bring an action to prohibit or to recover for the publication of those letters by the other. Sce Warren \& Brandeis at 207-13. It was concluded, however, that "[t] personal writings and any other productions of the intellect or of the emotions, is the right to privacy. ..."Id. at 213.

75. "If you may not reproduce a woman's face photographically without her consent, how much less should be tolerated the reproduction of her face, her form, and her 
"inviolate personality": ${ }^{78}$ certain aspects of each individual's life deserve protection from public scrutiny. ${ }^{77}$ Warren and Brandeis, therefore, made no distinctions between publicity that was true and publicity that was false; ${ }^{78}$ both merited condemnation.

The modern tort of invasion of privacy takes a more expansive view of the protected interests, ${ }^{79}$ though the ground for recovery has not been altered. An appreciation of the origins of the tort, however, provides a basis for distinguishing it froin defamation. The mental injuries suffered by a privacy plaintiff stein froin exposure of the private self to public view. The mental injuries suffered by a defamation victim, by contrast, arise as a consequence of the damage to reputation, either real or perceived. ${ }^{80}$ Thus, both torts provide redress for "wounded feelmgs," but the source of the harm differs substantially. ${ }^{81}$

actions, by graphic descriptions colored to suit a gross and depraved imagination." Warren \& Brandeis at 214. The focus of the Warren and Brandeis article was on the types of privacy now known as "publicity given to private affairs" and "false light privacy." See note 32 supra. See Kalven, supra note 32, at 330; Prosser, supra note 32, at 384.

76. See Warren \& Brandeis at 205. A tone of Victorian spirituality and "injured gentility" found throughout the article has been noted elsewhere. See Bloustein, supra note 32; Kalven, supra note 32, at 329.

77. It is unclear precisely which aspects are deserving of protection, at least where the publicity is truthful, because of the "newsworthiness" defense. This defense is available to publishers in all instances where the publicized statements are conceivably within the realm of legitimate public interest. Warren and Brandeis themselves first suggested this defense, see Warren \& Brandeis at 214-16, and courts have expanded the availability of the defense to include a wide range of events. Tinus, in one leading case, the peculiar habits of a former child prodigy, who desired only obscurity, were held to be within the public interest. See Sidis v. F-R Publishing Corp., 113 F.2d 806 (2d Cir. 1940). For a more complete discussion of the newsworthiness defense, see Pember \& Teeter, supra note 32, at 69-73 and cases cited therein. Time, Inc. v. Hill, 385 U.S. 374 (1967), extends the actual maliee standard to all false reports of "matters of public interest," $i d$. at 387-88, thereby imposing a limited newsworthiness defense when the reports are untrue.

Justice Marshall dissented in Rosenbloom partly because of his fear that implementation of the actual malice standard in the "matters of public interest" context would lead to the same substantial destruction of protection from defamation that the newsworthiness standard had brought about in cases of privacy. See Rosenbloom v. Metromedia, Inc., 403 U.S. 29, 80 (1971) (Marshall, J., dissenting).

78. Warren and Brandeis noted that the truth or falsity of the publicized statement is irrelevant when the protected right is that of privacy, since the mere publicity creates the cause of action: "The [right of privacy] implies the right not merely to prevent inaccurate portrayal of private life, but to prevent its being depicted at all." Warren $\&$ Brandeis at 218.

79. See note 32 supra.

80. See text accompanying notes $37-92$ infra.

81. "It is not for injury to the individual's character that redress or prevention is sought, but for injury to the right of privacy." Warren \& Brandeis at 218. See text accompanying notes $95-97$ infra. 


\section{B. Nature of the Injuries}

"Reputation" has always been an elusive concept to define. ${ }^{82}$ It has been suggested that reputation is a "relational" interest that takes its form from the relations one has with one's family, one's employer or customers, one's friends, and even society at large, where potential relationships exist. ${ }^{83}$ Reputation thus reflects one's economic relationships as well as one's "honor." 84 To the extent that reputation implicates the attitudes of third persons, it is a very tangible notion which can be ascertained with some sophistication by the objective techniques of modern social science. ${ }^{85}$ While these inethods may be infrequently

82. Traditionally, injury to reputation has been defined in terms of the hatred, contempt, or ridicule of others. See W. Prosser $\$ 111$, at 739 . This definitiou has since been expanded to include diminished esteem, respect, goodwill, or confidence in the plaintiff. See id. Receutly, however, an attempt has been made to view "reputation" from a psychological and linguistic standpoint. The word has been considered merely a symbol for a host of intellectual, behavioral and legal concepts, which include not only the external relationships an individual may have with others, but also his psychic reactions to the altered relationships. See Pound, supra note 67, at 445-53; Probert, Defamation, A Camouflage of Psychic Interests: The Beginning of a Behavioral Analysis, 15 VAND. L. REv. 1173, 1175-85 (1962).

83. See W. Prosser $§ 111$, at 737; Anderson, supra note 7, at 470-71; Green, Relational Interests, 31 ILI. L. REV. 35, 37-44 (1936); Probert, supra note 82, at 1178-79.

84. See notes 67-68 supra.

85. The relevant factor in defamation actions is, of course, plaintiff's reputed character and not what character he actually possesses. See $1 \mathrm{~J}$. Wigmore, Treatise oN EVIDENCE $\$ 70$ (3d ed. 1940). Social scientists have developed several means of measuring an individual's attitude and the degree of his attitude change. One technique measures attitude indirectly by presenting the individual with a series of "belief statements" which have been scaled according to whether the item expresses favorability or unfavorability toward the attitude object (in this case, the defamed person) and by asking the individual whether he agrees or disagrees with these statements. Another technique is to ask the mdividual directly for his evaluation of the attitude object and either to record his statement of "like" or "dislike" or to measure his physiological reaction to the question by some mechanical meaus. Still another method utilizes reports of past or intended behavior toward the attitude object. For a brief description of all of these techniques, see Himmelfarb \& Eagly, Orientations to the Study of Attitudes and their Change, in ReAdings IN ATtTTUde Change 2, 6-8 (S. Himmelfarb \& A. Eagly, eds. 1974). See also G. Summers, ATtitude Measurement (1970).

These methods might be applied to a significant sample of persons in plaintiff's community, or to all those who might reasonably be expected to have been exposed to the publication, by means of a poll or survey. Simple applications of such polling techniques have been made with some success in the criminal area as an aid to a motion for a change of venue or a continuance of the trial of an uupopular defendant. See Sherman, The Use of Public Opinion Polls in Continuance and Venue Hearings, 50 A.B.A.J. 357 (1964). It would seem, then, that such methods could be used to determine with some accuracy changes in third persons' attitudes toward plaintiff, that is, changes in plaintiff's reputation.

Thus, reputation is a considerably more concrete interest than the interest in mental comfort because it is susceptible to more objective proof and measurement. Damage to reputation can be ascertained with far more sophistication and accuracy than the wholly subjective injury of mental suffering. See note 86 infra. 
employed in practice, ${ }^{86}$ their theoretical usefulness serves to demonstrate the concreteness of the interest.

At common law, mental suffering was viewed not as a separate component of damages, but as an integral part of the general damages presumed from the defamation. ${ }^{87}$ Wigmore in his famous treatise on evidence states that "the injury to feelings which the law of defamation recognizes is not the suffering from the making of the charge, but is that suffering which is caused by other people's conduct towards [the plaintiff] in consequence of it."88 Thus, the emotional damage is really a reflection of the harm done externally: the plaintiff may think differently of himself as a result of the defamatory utterance. ${ }^{80}$ He may suffer harm to dignity, pride and self-esteem. ${ }^{90}$ It

86. Evidence of plaintiff's character has generally been held admissible either to mitigate or to enhance plaintiff's recovery. $1 \mathrm{~J}$. WIGMORE, supra note 85 , at $\S 70$. Whether such evidence is admissible when compiled by survey, however, poses a different set of problems. Survey evidence is generally admissible when the survey is conducted by recognized experts according to accepted scientific principles. See, e.g., Zippo Mfg. Co. v. Rogers Imports, Inc., 216 F. Supp. 670, 682 (S.D.N.Y. 1963); Zeisel, The Uniqueness of Survey Evidence, 45 CORNELI L.Q. 322, 345-46 (1960). Survey evidence, however, often violates the hearsay and opinion rules of evidence and has on this basis sometimes been excluded. See McCoid, The Admissibility of Sample Data into a Court of Law: Some Further Thoughts, 4 U.C.L.A. L. REv. 233, 235-47 (1957); Zeisel, supra, at 333-37. To some extent this difficulty is obviated by the "state of mind" exception to the hearsay rule, which permits admission of hearsay evidence offered to show a relevant present state of mind, attitude or belief on the part of the declarant. See Zippo Mfg. Co. v. Rogers Imports, Inc., 216 F. Supp. 670, 683 (S.D.N.Y. 1963); Zeisel, supra, at 333-34. Since the matter in question is reputed character, a determination which is dependent on the attitudes of the survey interviewees, the hearsay problem can be substantially avoided.

The major difficulty for the litigant is the expense of such a survey. The scientific validity of the survey is an important criterion for its admissibility, and the cost of conducting a scientifically valid survey would probably be prohibitive for most plaintiffs. Thus, even if the hearsay problem is surmounted, this remaining difficulty obviously makes the use of such surveys largely impractical.

87. See note 31 supra.

88. $1 \mathrm{~J}$. WIGMORE, supra note 85 , at $\S 209$. Wigmore emphasizes that "[r]eputation is the ultimate fact" and that "the harm for which compensation is asked is the loss of social relations, as involved in the diminished reputation of the plaintiff." Id. Thus, recovery for mental injuries is merely consequential to the damage to reputation. But see Kelly v. Loew's, Inc., 76 F. Supp. 473, $488-89$ (D. Mass. 1948); Curley v. Curtis Publishing Co., 48 F. Supp. 27, 28 (D. Mass. 1942).

89. See Probert, supra note 82 , at $1179-85$ :

Since reputation is not something which exists separate from a person, since as a term it is included in the field of terms bearing on human behavior, and since usually the person is affected whose reputation is affected, then that person may be affected in ways we will more readily recognize as intra-personal rather than inter-personal. While the defendant's utterance may suggest what he thinks of plaintiff and may give some basis for our inferring how some others may come to think of plaintiff, it may also give a basis for inferring what plaintiff may feel about himself and others. Id. at 1181 .

This conclusion also follows as a consequence of Wigmore's observation, see note 88 supra and accompanying text, since the mental injuries flow from a damaged reputation.

90. See Probert, supra note 82, at 1181. 
will be recalled that the common law did not distinguish between defamation which actually harmed reputation and defamation which tended to harm reputation. ${ }^{91}$ It follows that the mental suffering element of defamation arises from a fear that others might behave differently toward the defamed person rather than from the certainty that they in fact $d o$ behave differently. ${ }^{92}$

It is difficult to imagine, however, why a plaintiff may think differently of himself when others do not think differently of him. Since the common law presumed harm from defamatory falsehoods, this inconsistency was never manifest. ${ }^{93}$ By eliminating presuined damages, Gertz reveals this inconsistency and raises the question of whether mental imjuries unrelated to actual harm to reputation should be compensated for in a defamation action. Mental injuries in such a case seem to arise from publicity and not from the altered conduct of third persons. $^{94}$ Thus, an action in privacy appears to be more appropriate.

The mental injuries whicli result from invasion of privacy do not differ substantially from the mental injuries in defamation. The privacy plaintiff suffers embarrassment and humiliation, which are virtually indistinguishable from harm to pride and self-esteen. ${ }^{95}$ In defaination actions, however, the injuries result from real or imagined harm to reputation, an objectively determinable interest. ${ }^{96}$ In privacy actions the injuries arise solely from public exposure of private facts. ${ }^{97}$ The subjective character of these injuries is mitigated only by the requirement that the exposure be "highly offensive to a reasonable person"98 or to a person of "ordinary sensibilities." 99 This requirement is designed to safeguard agamst trivial claims, ${ }^{100}$ but its efficacy is questionable; ${ }^{101}$ adequate protection of free speech interests would appear to

91. See text accompanying notes 27-30 supra.

92. See Anderson, supra note 7, at 471; cf. Probert, supra note 82, at 1182.

93. See note 40 supra and accompanying text.

94. See text accompanying notes 165-66 infra.

95. Indeed, humiliation is defined in terms of lost pride and self-esteem. See WEBSTER'S NEW INTERNATIONAL DICTIONARY 1101 (3d ed. 1961).

96. See text accompanying notes 82-86 supra.

97. See text accompanying notes 70-78 supra.

98. See Restatement $\$ \$ 652 D-652 E$ (Tent. Draft No. 22, 1976). See also W. PROSSER $\$ 117$, at 813 and cases cited therein.

99. See Prosser, supra note 32, at 396-97.

100. See RestatemenT $\$ 652 \mathrm{E}$, comment $\mathrm{c}$ at 33 (Tent. Draft No. 22, 1976); Prosser, supra note 32, at 396-97.

101. At least one commentator has viewed this requirement as insufficient, since "the upshot is that every unconsented-to reference in the press creates prima facie a cause 
require the retention of the current actual malice standard..$^{102}$

\section{C. "Pure" Mental Injury and the Common Law}

Because defamation and invasion of privacy both contain elements of mental injury, a comparison of these torts with cases of "pure" mental injury helps to provide an understanding of the different policies at stake. Pure mental injury is that which is unaccompanied by any other legal invasion of the rights of the imjured party. ${ }^{103}$ Recovery for pure mental injury has been allowed only recently ${ }^{104}$ because of the common law's fear of the administrative and philosophical difficulties which would arise from actions based solely on mental distress. The primary concerns were with the potential for trivial or fictitious claims, ${ }^{105}$ the impossibility of determining damages, ${ }^{106}$ and the problems of establishing causation. ${ }^{107}$ Modern jurisprudence views the first difficulty as the only one of real substance, ${ }^{108}$ and gradually the tort of "infliction of emotional distress" has come to be recognized. ${ }^{109}$

The evolution of this tort has depended on advances in botli science and the law. Medical science is now able to detect physical manifestations of mental injuries with some certainty, thereby reducing the danger of imposture. ${ }^{110}$ The law has recognized that mental imjuries may occur without any precedent physical injury, ${ }^{111}$ and that adherence

of action that could take the plaintiff to the jury." See Kalven, supra note 32, at 334 . Once before the jury, plaintiff can recover a large verdict because of the difficulties of proving the mental injuries: "[I]t remains odd to give recovery for emotional disturbance without any showing that plaintiff suffered or was upset." Id. These difficulties, plus the added "lack of legal profile" for the tort, raise the question of whether the right of privacy should be recognized at all. See id. at 337. Though it is unlikely the courts will abandon their recognition of the right, the problems raised by Professor Kalven are important factors to consider in the determination of whether the Gertz primciples should be extended into the law of privacy. See text accompanying notes 12637 infra. But cf. Wade, supra note 32, at 1122-23.

102. See text accompanying notes 126-44 infra.

103. See W. Prosser \& 12, at 49-50; cf. Warren \& Brandeis at 197 n.1.

104. See W. Prosser $\S 12$, at 52-53. See generally RESTATEMENT $\S 46$, comments $\mathrm{b}$ and $\mathrm{c}$ at 72.

105. See W. Prosser $\S 12$, at 51 and cases cited therein.

106. "Mental pain or anxiety the law cannot value, and does not pretend to redress, when the unlawful act causes that alone." Lynch v. Knight, 9 H.L.C. 577, 598, 11 Eng. Rep. 854 (1861), quoted in W. Prossen $\$ 12$, at 50.

107. See W. Prosser $\S 12$, at $50-51$ and cases cited therein.

108. See id. at 51 .

109. See RESTATEMENT $\S 46$.

110. See W. Prosser $\S 54$, at 328 and authorities cited therein.

111. Prior to recognition of the mental distress tort, the law required that there be some physical "impact" upon plaintiff before recovery could be had for any mental injuries. Thus, the courts conditioned recovery upon proof of assault, battery, false im- 
to the ideal of making every plaintiff whole requires compensation for such imjuries.

The law does, however, impose stringent safeguards to ensure that the mental injury has in fact occurred. First, recovery is restricted to those instances where the tortious conduct is "shocking" or "outrageous." 112 Second, the vast majority of jurisdictions require that the mental distress be accompanied by physical symptoms before recovery will be allowed. ${ }^{113}$ Even in those jurisdictions which have no requirement of physical symptoms, the circumstances of the tort must be such as to ensure the fact of emotional upset. ${ }^{114}$ Fimally, the almost universal ruling of the courts has been that the tortious conduct, in addition to its outrageous character, must be intentional. ${ }^{115}$

These safeguards have traditionally been thought unnecessary in defamation actions because the defainatory character of the falsehood has itself been considered sufficient proof of ijuries to reputation and mental comfort. ${ }^{116}$ After Gertz, however, dainages may not be

prisonment, trespass or nuisance, no matter how slight or evanescent the "touching" may have been. See generally id. $\$ 12$, at 55-56. It appears that now, however, the law has come full-circle, at least with respect to intentional torts, so that "conduct which is tortious because intended to result in bodily harm to another or in the invasion of any other of his legally protected interests does not make the actor liable for an emotional distress which is the only legal consequence of his conduct." RESTATEMENT $\$ 47$.

The law requires that the emotional upset in fact occur and that it be severe. The emotional distress may include such reactions as "fright, horror, grief, shame, humiliation, embarrassment, anger, chagrin, disappointment, worry, and nausea." RESTATEMENT $\$ 46$, comment $j$ at 77 . These injuries may also result from either defamation, see text accompanying note 90 supra, or invasion of privacy, see text accoinpanying note 95 supra, but the difference is one of degree:

It is only where [the injury] is extreme that the liability arises. Complete emctional tranquility is seldom attainable in this world, and some degree of transient and trivial emotional distress is a part of the price of living among people. The law intervenes only where the distress inflicted is so severe that no reasonable man could be expected to endure it. RESTATEMENT \& 46, comment $\mathrm{j}$ at 77.

By contrast, defamation and privacy impose no requirement that the mental injuries be severe, since the legal invasion of right is considered adequate proof of the mental injury.

112. This requirement must be met in order for the action to be successful regardless of whether defendant acted intentionally or with malice. See RESTATEMENT $\$ 46$, cominent $d$ at 72-73. The law is stringent in imposing this requirement. Id.

113. See W. PROSSER $\$ 12$, at 59 and cases citcd therein.

114. See id. at 59-60 and cases cited therem. The Restatement adopts this latter position. See Restatement $\$ 46$, comment $k$ at 78 . For examples of the type of outrageous behavior which by itself "carries conviction that there has in fact been severe cmotional distress," see the illustrations to comment $\mathrm{k}$.

115. See W. Prosser $\S 12$, at 60 ; Restatement $\$ 46$, comment $i$ at 77 . A few cases have permitted liability on a mere showing of recklessness, see cases cited in W. PROSSER $\S 12$, at 60 , and the Restatement also acknowledges this approach. See RESTATEMENT $\$ 46$, comment $i$ at 77 . The "actual malice" standard established by the Supreme Court in defamation and privacy cases also involves recklessness. See note 14 supra.

116. See text accompanying notes 29-31 supra. 
presumed from the defamatory character of the words; proof of actual injury and fault on the part of the defendant are required. ${ }^{117}$ By rejecting the doctrine of presumed damages, the Court made clear that basing recovery on the mere defamatory character of the words does not provide adequate protection against trivial claims in light of the first amendment interests involved. Similarly, in privacy actions the public exposure of private facts has been deemed adequate evidence of the fact of injury, so long as the exposure is sufficiently offensive. ${ }^{118}$ In Time, Inc. v. Hill, ${ }^{110}$ however, the Supreme Court felt the additional protection of the actual malice standard was necessary to avert the danger of self-censorship.

\section{Reconciliation: Defamation, Privacy AND FREE SPEECH}

With its recognition in Firestone that a defamation plaintiff need only prove mental suffering in order to recover damages, ${ }^{120}$ the Supreme Court inay have effectively extended the Gertz principles into the area of privacy. Firestone, however, is not a privacy case. It is unclear, therefore, how the Court will respond when faced with a privacy case which presents the contention that the actual malice standard is inappropriate where plaintiff is not a public figure. Three alternatives appear open to the Court: (1) explicitly extend the Gertz principles into the privacy area; (2) distinguish privacy from defamation and retain the actual malice standard in all privacy cases; or (3) modify Firestone and require that in defamation actions actual harm to reputa. tion must be shown as a prerequisite to recovery for mental suffering.

117. See text accompanying notes 53-57 supra.

118. Warren and Brandeis created the right of privacy so that mental injuries resulting from unwarranted publicity might be redressed. See text accompanying notes 70 78 supra. The Restatement declares that a plaintiff who has established that his privacy has been invaded may recover for mental injury suffered "if it is of a kind which normally results from such an invasion, and it is normal and reasonable in its extent." RESTATEMENT $\S 652 \mathrm{H}$, comment b at 40 (Tent. Draft No. 22, 1976). The Restatement seeks to avoid the presumed damages problem by requiring that plaintiff "prove" the mental injuries he "actually" suffered. See id. Its reliance upon such words as "normally" and "normal and reasonable," however, indicates the inherent difficulty of proving actual damages from mental injury. See id. The Restatement's dilemma, therefore, suggests that Professor Kalven is correct when he states, "The theory of damages [in privacy] is equally vague and mysterious insofar as damages are supposed to be compensatory." Kalven, supra note 32, at 334. Mental injuries, even when coupled with an invasion of the right of privacy, are simply too tenuous to support a claim for compensation on a showing of mere negligence. See text accompanying notes 141-44 infra. Cf. Anderson, supra note 7, at 471-72.

119. 385 U.S. 374 (1967).

120. See notes 61-62 supra and accompanying text. 


\section{A. Extending Gertz to Privacy Cases}

An extension of the Gertz principles into the privacy area would mean that a privacy plaintiff's burden would vary according to whether he was a public figure or a private individual. ${ }^{121}$ The rationale for the public-private plaintiff distinction in the defamation area is that the public figure assumes the risk of defamatory falsehood by thrusting himself into the public view. ${ }^{122}$ Since he has voluntarily assumed his position, ${ }^{123}$ he cannot expect the same protection as can a private individual who has not sought public exposure. Moreover, his prominence as a public figure provides him with greater opportunity to rebut defamatory charges. ${ }^{124}$ The private individual does not have the same access to a public forum to protest false statements about him. For these reasons, he is held to be deserving of greater protection ${ }^{125}$ and need only prove negligence to recover for defamation.

Viewed solely from the perspective of the plaintiff's interests, this rationale should apply with equal force in the privacy area, since a public figure's voluntary exposure permits increased scrutiny of his private life by the media. When viewed from the defendant's perspective, however, the inappropriateness of extending the Gertz distinction to privacy cases becomes apparent: such an extension ignores the dif-

121. Cf. Gertz v. Robert Welch, Inc., 418 U.S. 323, 344-46 (1974).

122. See id. at 345. The basis for this distinction comes from Chief Justice Warren's concurring opinion in Curtis Publishing Co. v. Bntts, 388 U.S. 130, 164-65 (1967) (Warren, C.J., concurring). That case extended the New York Times standard to instances in which plaintiff is a public figure. Chief Justice Warren reasoned that the modern era had brought together the governmental and private sectors and there was simply no reason to apply a different standard to those who moved back and forth along the interface. See id. at 163-64. Consequently, the first amendment required that defendants should be permitted the same "breathing space" irrespective of whether the plaintiff is a public official or a public figure. See id. at 148-49, 163 .

Gertz adopted the Chief Justice's rationale but also expanded upon it. The Court noted that individuals may achieve public figure status in different ways. 418 U.S. at 345. All public figures, however, must prove actual malice to be successful in their suit.

The Court's emphasis in Gertz on the relationship between public figures and "particular public controversies," id. at 351-52, might be viewed as a return to the Rosenbloom rationale of protection of all matters of "public or general concern." $C f$. Rosenbloom v. Metromedia, Inc., 403 U.S. 29, 44 (1971). The Court explicitly rejected this standard, however, because "it would occasion the additional difficulty of forcing state and federal judges to decide on an ad hoc basis which publications address issues of 'general or public interest' and which do not. . ." 418 U.S. at 346. Nevertheless, in Time, Inc. v. Firestone, 424 U.S. 448 (1976), the Court made this ad hoc determination, see id. at 454, prompting a vigorous dissent from Justice Marshall who viewed Mrs. Firestone as a public figure. See id. at 484-90 (Marshall, J., dissenting).

123. Gertz v. Robert Welch, Inc., 418 U.S. 323, 345 (1974).

124. Id. at 344 .

125. Id. 
fering degrees of protection for defendants which are inherent in defamation and privacy actions.

Defamation actions have traditionally provided compensation for injury to reputation and consequential mental suffering, ${ }^{126}$ while privacy actions compensate directly for mental suffering, a far inore subjective form of injury. ${ }^{127}$ The law has always recognized the difficulty of assessing or even detecting mental suffering in the absence of an underlying concrete injury. ${ }^{128}$ While injury to reputation has frequently been difficult to prove, the difficulty generally arose from the problem of procuring witnesses and from other external circumstances rather than from the intrinsic nature of the injury. ${ }^{128}$ The Gertz Court, perhaps perceiving this fact, abolished presumed damages and imposed an actual injury requirenent to limit defendant's liability. ${ }^{130}$

In privacy actions, however, as in most other tort actions, the plaintiff has always been required to show actual injury. ${ }^{131}$ The danger of excessive verdicts in privacy actions arises froin the nature of the injury itself rather than from extrinsic circumstances. ${ }^{132}$ Thus, while

126. See text accompanying notes 26-31 supra.

127. See note 36 supra and accompanying text.

128. See text accompanying notes 104-07 supra.

129. See note 30 supra. Reputation is an objectively quantifiable relational interest, see note 85 supra and accompanying text, and hence third parties could testify as to their attitude toward plaintiff before and after the defamatory communication. See C. MCCoRmick, Handbook on tHe LAw of Damages $\$ 117$, at 429 (1935); cf. Anderson, supra note 7, at 470-71. The distinction between injury to such an interest and mental suffering is that in the former the changed attitudes of third persons mark the degree of damage while in the latter only the changed attitude of the plaintiff is relevant. The relative unreliability of the testimony of the plaintiff is self-evident. See, e.g., id. at 472 . In Firestone, plaintiff's claim of mental suffering was supported by the testimony of her minister, friends, and doctor. The doctor had adıninistered a single sedative to her and described the degree of her anxiety. 424 U.S. at 460 n.6. Plaintiff also testified as to her fear that her young son might be adversely affected when he grew older. Id. at 461. Such testimony, of course, is all that might be expected when the injuries are purely mental, and in the physical torts, such testimony adequately supports claims of "pain and suffering." These cases, however, do not involve problems of self-censorship and the first amendment, and furthermore, the relationship between the physical injury and the mental injury limits the extent of defendant's liability for pain and suffering. See note 162 infra and accompanying text.

130. See text accompanying notes 53-57 supra. The actual injury requirement is intended as the primary protection for the media against excessive jury verdicts. See Gertz v. Robert Welch, Inc., 418 U.S. 323, 349 (1974); Rosenbloom v. Metromedia, Inc., 403 U.S. 29, 66 (1971) (Harlan, J., dissenting). "The size of the potential judgment that may be rendered against the press must be the most significant factor in producing self-censorship. . . ." Id. at 82 (Marshall, J., dissenting); see id. at 82-84.

131. The doctrine of presumed damages was unique to defamation and trespass. See Gertz v. Robert Welch, Inc., 418 U.S. 323, 349 (1974); W. Prosser $\$ 13$, at 66.

132. Several commentators expressed concern after Gertz that the actual injury requirement might be an inadequate protection against self-censorship if damages for mental injury alone were allowed: 
the actual mjury requirement in Gertz is intended to compensate defendants for the lower measure of constitutional protection available to them when private plaintiffs bring the suit, ${ }^{133}$ no similar compensating feature would exist in privacy actions if a negligence standard were to be imposed. The only comparable protection for defendants in privacy actions is found in the requirement that the tortious conduct be "highly offensive to a reasonable person"; ${ }^{134}$ but the presence of first amendment considerations inandates soine stricter form of protection. ${ }^{135}$ Absent such protection, there is little to stand in the way of trivial claims and excessive jury verdicts, with the ever-present possibility of media self-censorship. ${ }^{136}$ The problem is compounded by the enormous discretion allotted jurors in determining what is adequate compensation for injuries. ${ }^{137}$

It is difficult to see how injuries such as 'personal humiliation' and 'mental anguish' can be established except by a process that in practice will be little different from presuming them. The plaintiff will have to produce some proof of his emotional injury-such as his own testimony that he felt humiliation and mental anguish-but beyond that the jury surely will infer the existence, nature, and extent of those injuries from the nature of the defamatory statement. Thus, emotional injuries, though not presumed, will be inferred. Such an insignificant change in practice seems unlikely to reduce substantially the amount of awards for emotional imjuries. Anderson, supra note 7 , at 472 .

See also Eaton, supra note 7, at 1437-39. Justice Brennan dissented in Firestone in part because he believed that "by allowing this type of recovery the State has subverted whatever protective influence the 'actual injury' stricture may possess." 424 U.S. at 475 n.3 (Brennan, J., dissenting).

133. Cf. Gertz v. Robert Welch, Inc., 418 U.S. 323, 348-49 (1974); Anderson, supra note 7 , at 424 .

134. See text accompanying note 98 supra.

135. Of course, it does not follow that so long as libel law performs the same compensatory function as civil law generally it is necessarily legitimate in all its various applications. The presence of First Amendment values means that the State can be compelled to utilize finer, more discriminating instruments of regulation where necessary to give inore careful protection to these countervailing interests. Rosenbloom v. Metromedia, Inc., 403 U.S. 29, 68-69 (1971) (Harlan, J., dissenting).

136. See notes 129,132 supra. Compare the experience of the law with "pure" memtal injury, discussed in text accompanying notes 103-15 supra.

137. The court determines what injuries are compensable but the jury deterinines the amount of damages recoverable for those injuries. Other than such linnitations as the use of the reunittitur or the granting of a new trial, juries have very wide discretion in inaking their determination. See generally C. McCosmick, supra note 129, at 24-28. Limitations on the jury, however, are exercisable only to guard against excessive verdicts "dictated by passion and prejudice." See F. HARPER \& F. JAMES $\S 5.29$. Thus, in practice these limitations are often ineffective. For example, in Rosenbloom, the plaintiff, charitably characterized by the Court as a "distributor of nudist magazines," 403 U.S. at 32, was initially granted a verdict of $\$ 750,000$. Id. at 40 . The trial court reduced this sum on remittitur to $\$ 275,000$, still a substantial sum. Id. Similarly, in Butts the reinittitur reduced an award of $\$ 3,060,000$ to $\$ 460,000,388$ U.S. at 138 , and in Walker froin $\$ 800,000$ to $\$ 500,000$, id. at $141-42$ (punitive damages disallowed). Furthermore, in many cases the court allows the verdict to stand without reduction. See, 
Similar problems with potentially excessive damages and trivial claims are found in connection with the tort of infliction of emotional distress, where the injuries are also purely mental. ${ }^{138} \mathrm{~A}$ safeguard is provided in emotional distress actions by the alternative requirements that external physical symptoms of the mental disturbance be present or that the defendant's conduct be "extremely outrageous." "139 The law further requires that the conduct be intentional, both to supply additional proof of the existence of injury and to promote the policy of imposing greater responsibility on those who intend the harm they bring about. ${ }^{140}$

Analogous safeguards would seem to be required in the privacy area. Although it is apparently assumed in privacy cases that the publicity itself is sufficient proof that damage has occurred, ${ }^{141}$ the danger of imposture is no less when there has been publicity than when there. has not, since the very fact of mental injury is still so difficult to detect. ${ }^{142}$ The requirement that the tortious conduct be "highly offensive to a reasonable person" offers little protection, because of the possibility that a "thick-skinned" plaintiff might recover for injuries he never suffered. ${ }^{143}$ In effect, then, the defendant's conduct is being punished rather than the plaintiff's injury being compensated. The actual malice standard propounded in Time, Inc. v. Hill would, however, guard against trivial claims and excessive verdicts in much the same way as do the physical injury and intent requirements in emotional distress cases and the actual injury requirement in defamation cases. ${ }^{144}$ The

e.g., New York Times Co. v. Sullivan, 376 U.S. 254, 256 (1964) ( $\$ 500,000)$; Sprouse v. Clay Communications, Inc., - W. Va. -, 211 S.E.2d 674, cert. denied, 423 U.S. $882(1975)(\$ 250,000)$. For differing views of the effect of Gertz on judicial limitations of jury verdicts, compare Robertson, supra note 7, at 233-34, with Anderson, $A R e$ sponse to Professor Robertson: The Issue Is Control of Press Power, 54 Texas L. Rev. 271 (1976).

138. See text accompanying notes 103-09 supra.

139. See text accompanying notes 112-14 supra.

140. "Intent" as defined by the Restatement indicates that the actor desires certain consequences to follow or that he believes that the consequences are substantially certain to follow from his actions. See Restatement \& 8A. Where the defendant has intended to do harm, "[m]ore liberal rules are applied as to the consequences for which he will be held liable, the certainty of proof required, and the type of damage for which recovery is to be permitted, as well as the measure of compensation." $W$. Prosser $\S 7$, at 30. The reason for this liberality is the law's tendency to accord less weight to a defendant's interests "when moral iniquity is thrown into the balance." Id. at 30-31.

141. See note 118 supra and accompanying text.

142. See note 118 supra and text accompanying notes 105-09 supra.

143. See generally Kalven, supra note 32, at 338-39.

144. The actual malice standard operates as a high threshold barrier to prevent the suit from ever reaching the damages question. See Pember \& Teeter, supra note 32, at 83-87. Thus, while the actual malice standard does not guarantee the fact of injury, 
inadequacies of an extended Gertz private plaintiff standard argue strongly for retention of the actual malice test in all privacy actions.

\section{B. Distinguishing Defamation and Privacy}

Any attempt by the Supreme Court to distinguish privacy from defamation must be predicated upon either the character of the words used by the defendant or upon the nature of the mjury sustained by the plaimtiff. By holding in Firestone that damages for mental injuries alone may be recovered on a showing of negligence in a defaination action brought by a non-public figure, the Court indicated that the latter distinction may no longer be valid. ${ }^{145}$ The Court had previously lent affirmative support to a distinction based on the character of the words when it stated in Gertz that the negligence standard is available only where "the substance of the defamatory statement 'makes substantial danger to reputation apparent." "148 Conversely, no view was expressed as to the possible disposition of cases where a factual misstatement "[does] not warn a reasonably prudent editor or broadcaster of its defamatory potential."147 If the Court were to rely on this distinction in the future, then non-defamatory false light privacy cases, and defamation cases where extrinsic facts are necessary to inake out the defamatory meaning, ${ }^{148}$ would be judged against the actual malice standard. All other privacy and defannation cases brought by private figures would be governed by a lesser standard of liability.

From one point of view this distinction is appropriate, since the apparent purpose of the Gertz opinion is to require some diligence on the part of the media without inducing self-censorship. ${ }^{149}$ A defendant who has warning of the defannatory potential of a statement might be expected to take measures to ensure the accuracy of his report. A defendant who has no warning, lowever, cannot reasonably be expected to take such precautions. To impose a penalty on the second

as perhaps these other safeguards do, it at least possesses the virtue of vastly reducing the possibility of trivial claims and the dauger of imposture.

145. See notes 60-62 supra and accompanying text.

146. 418 U.S. 323,348 (1974).

147. Id.

148. Where extrinsic facts are necessary to make out the defamatory meaning, the tort is denominated "libel per quod." See note 29 supra. The Restatement of Torts views the Gertz Court's language as an indication that the standard of reasonableness will govern the determination of whether a statement was defamatory on its face or not. thereby eliminating the common law rule of strict liability in this situation, and perhaps also, libel per quod. See Restatement $\$ 580 \mathrm{~B}$, commeut c at 28-29 (Tent. Draft No. 21, 1975).

149. See Gertz v. Robert Welch, Inc., 418 U.S. 323, 348-49 (1974). 
defendant on proof of mere negligence might lead to excessive selfcensorship, since a publisher may often have little basis for assessing the ultimate defamatory impact of a statement at the time of publication. ${ }^{150}$

While this approach achieves the obviously desirable goal of imposing greater liability on those who are most at fault, ${ }^{151}$ it fails to give adequate consideration to the problem of assessing damages. ${ }^{152}$ Discussion in the previous section indicated that the principal difficulty with eliminating the actual malice standard in the privacy area is that neither the existence nor the extent of inental suffering can be proved with sufficient precision to avoid trivial claims or excessive damages. ${ }^{153}$ It follows that damages for mental suffering cannot be adequately determined in the absence of an underlying concrete imjury even if the statement is defamatory. Trivial claims might still be brought by dissembling plaintiffs in the hope of persuading juries of the existence of speculative mental injuries. Furthermore, it will be the rare case where an excessive jury verdict will be overturned, or even reduced to a sum which will not have a severe impact on free speech. ${ }^{154}$ Therefore, to permit recovery for such imjuries on a showing of mere negligence inadequately protects the media froin jury "punishment" for espousing unpopular opinions.

Additionally, in spite of the fact that this approach may follow more readily froin the literal terms of Gertz and Firestone, ${ }^{155}$ its adop-

150. A classic case of libel per quod involved a newspaper article which announced the birth of twins to a certain woman in the community. Unfortunately, the woman had only been married a month, and there were readers of the newspaper who were aware of this fact. See Morrison v. Ritchie \& Co., [1902] 4 Fraser, Sess. Cas. 645, 39 Scot. L. Rep. 432, cited in W. Prosser $\$ 112$, at 763 n.30. Clearly, to allow recovery in such a situation on a showing of mere negligence would lead to frequent instances of self-censorship by the media.

151. The negligent defendant is held liable where the defamatory potential of the statement is reasonably apparent, while the faultless defendant escapes liability altogether. Furthermore, the defendant who acted recklessly or intentionally is held liable even where the defamatory potential of the statement is not apparent. See note 51 supra.

152. Gertz instituted the actual injury requirement to compensate defendants for their loss of protection when a private plaintiff brings the suit. See 418 U.S. at 348-49. A distinction based on the character of the words, therefore, must take into account the nature of the injury to determine whether the actual injury requirement effectively serves its purpose with respect to the particular injury; undue reliance on the standard of fault requirement would defeat this compensating aspect of Gertz. In this regard, it is pertinent to note that the discussion in Gertz of the character of the words came prior to the discussion of the actual injury requirement. See id. at 348, 349-50.

153. See text accompanying notes 131-40 supra.

154. See note 137 supra.

155. See text accompanying notes $145-47$ supra. 
tion would be fundamentally inconsistent with the logic of Gertz. The suggested distinction between defamation and privacy focuses on the character of the words used by the defendant rather than on the nature of the injury suffered by plaintiff. The doctrine of presumed damages also focused on the character of the words, since it was the "tendency" of the words to injure reputation which gave rise to the presumption of injury. Thus, the character of the words became significant only as an aspect of the doctrine of presumed damages. Gertz, however, expressly held that damages may no longer be presumed in this manner and that proof of actual injury is required..$^{158}$ Elimination of that doctrine, therefore, appears to require a significant reduction in emphasis upon the character of the words used, that is, the "tendency" aspect of the definition, if injury to reputation is to remain the essence of the tort. ${ }^{157}$

\section{Proof of Harm to Reputation as a Prerequisite to Recovery for Mental Suffering}

Either of the first two approaches is readily reconcilable with the language of the Firestone opinion, but each poses the threat of selfcensorship because of the difficulty of determining damages for mental suffermg when this imjury is unaccompanied by harm to other interests. The Court apparently failed to perceive the interrelationship between presumed damages and the recognition of mental suffering as a compensable injury. Courts have always viewed mental suffering as an element of the dainages presumed from the utterance of a defamatory falsehood rather than as a separate component of damages. ${ }^{158}$ Because recovery for mental suffering was so integrally related to the doctrine of presumed damages, the Court's abolishment of that doctrine in Gertz should necessitate close examination of the wisdom of perinitting compensation solely for mental suffering in defamation actions.

A third approach, accordingly, would call for the Court to retreat from Firestone and its implications and require that actual injury to reputation be shown as a condition to recovery for mental imjury in defamation actions. Coupled with the Court's prior statement that the negligence standard should be imposed only where the defamatory potential of the statement is reasonably apparent, ${ }^{158}$ the effect of this re-

156. See notes 53-57 supra and accompanying text.

157. "[D]amage to reputation is, of course, the essence of libel." Monitor Patriot Co. v. Roy, 401 U.S. 265, 275 (1971).

158. See note 31 supra and accompanying text.

159. 418 U.S. at 348. 
quirement would be that the lesser standard of fault is applicable only in situations where the defamatory potential was reasonably apparent and there had been actual harm to reputation. ${ }^{160}$ In all other cases, the plaintiff would be required to prove actual malice. Invocation of the negligence standard on facts like those of Firestone would therefore be precluded. This approach avoids the deficiency apparent in the first two approaches-the difficulty of detecting and determining mental injury which is unaccompanied by other tangible harm.

Since injury to reputation is susceptible of objective proof, ${ }^{161}$ it can be determined with no greater difficulty than that encountered in proving injuries in the physical torts. Where "pain and suffermg" damages are assessed in the physical torts, the extent of physical damage provides some guidance as to the extent of mental damage, since by hypothesis there is some relationship between the two classes of injuries. $^{162}$ Similarly, in defaination the difficulties of valumg the extent

160. The last two situations discussed in the text can be illustrated graphically in the following manner:

A. Distinction on the Basis of the Words:

\begin{tabular}{l|c|c|}
$\begin{array}{l}\text { Mefamatory on } \\
\text { its face }\end{array}$ & Negligence & $\begin{array}{c}\text { Mental Injury and } \\
\text { Harm to Reputation }\end{array}$ \\
\hline $\begin{array}{l}\text { Not defamatory } \\
\text { on its face }\end{array}$ & Actual Malice & Negligence \\
\hline
\end{tabular}

B. Harm to Reputation as Prerequisite to Recovery for Mental Suffering: Mental Injury Only

Mental Injury and Harm to Reputation

Defamatory on its face

Not defamatory on its face

\begin{tabular}{|c|c|}
\hline Actual Malice & Negligence \\
\hline Actual Malice & Actual Malice \\
\hline
\end{tabular}

These charts demonstrate that the only difference in the standard of liability between the two analyses is in the situation where the statement is apparently defamatory but only mental injuries have resulted, as in the Firestone case. The reason for the higher standard of liability in situation $B$ is the essential inadequacy of the actual injury requirement where only mental suffering has occurred. To maintain the high level of protection which the actual injury requirement was intended to provide, a strict standard of fault is necessary in this situation. See note 152 supra.

161. See note 85 supra and accompanying text.

162. Although "pain and suffering" damages are as difficult to assess as damages for mental distress, see D. DobBs, HANDBook on tHe LAW of Remedies 544-45 (1973); C. MCCorMICK, supra note 129 , at 315-19, these damages are consequential to recovery for the physical damage which is the basis for the action. Since they are consequential damages, there is a relationship between the two injuries, and the determination of the "reasonableness" of the award for mental suffering is limited by that relationship. See generally RESTATEMENT § 905 (Tent. Draft No. 19, 1973). 
of mental injury are reduced because of the relationship between this injury and injury to reputation. ${ }^{163}$ A court would have ample grounds for limiting recovery for mental injury if the recovery bore no reasonable relationship to compensation for injury to reputation. As with the physical torts, then, a negligence standard in such cases is not at all inappropriate. ${ }^{164}$

Furthermore, adoption of this approach would clarify matters by emphasizing the theoretical distinctions between defamation and privacy. The mental injury a plaintiff suffers can arise either froin injury to his reputation or from the publicity given his private affairs. If plaintiff proves that his reputation has in fact been imjured, the clear indication is that his mental suffering arose from damage to that interest. In such a case, an action in defamation would be appropriate, since reputation is the interest defamation is designed to protect. ${ }^{165}$ If plaintiff is unable to prove that his reputation has been imjured, however, it would appear that his mental suffering must have arisen froin the publicity given the private facts rather than in response to the altered conduct of third persons. Protection from public exposure of private facts is the interest which privacy is designed to vindicate. ${ }^{166}$ Since there has been no injury to reputation, the action should lie in privacy.

Thus, a requirement that actual harm to reputation be shown as a predicate to recovery for mental imjuries protects the publisher from the potentially large verdicts recoverable under a negligence standard. If a private figure brimgs an action in defamation but is unable to prove injury to reputation, then he should not be permitted to recover for mental injuries unless it be shown that the publisher acted with actual malice.

163. See notes $87-90$ supra and accompanying text.

164. The law determines its standard of liability in particular types of cases by a balancing process. Thus, in intentional torts, defendant's conduct is thought to be so morally blameworthy that the law deems it appropriate that the defendant suffer fully for the consequences of his act. Similarly, in cases of strict liability, defendant's conduct is abnormally and inherently dangerous and he will be held liable for his activities even without a showing of fault. See W. PROSSER $\$ 75$, at 494-96. In torts involving negligence, however, the competing interests are more nearly in equilibrium, and a balance is struck between the magnitude of the risk and the utility of the conduct. See RESTATEMENT \$ 291-93. See generally W. Prosser \$ 4. See also Wade, supra note 7, at 3-5. When this analysis is applied in the context of privacy law, it seems apparent that the utility of a defendant's conduct, that is, the unimpeded publication of matters of public interest, far outweighs any right of plaintiff to his privacy, at least where the only injury to plaintiff is indeterminate mental suffering and where the risk of self-censorship is therefore exceedingly high.

165. See note 66 supra and accompanying text.

166. See note 70 supra and accompanying text. 


\section{ConClusion}

The Supreme Court has labored for more than a decade to arrive at a proper resolution of the conflict between the state interest in protection of an individual's reputation and the first amendment's protection of free speech. The Firestone case uncovered new difficulties for the Court in the defamation area and raised the further question of how the Court will dispose of a privacy case brought by a non-public figure. Together, Gertz and Firestone suggest two possibilities: (1) either the Gertz principles will be extended into the privacy area in all privacy cases; or (2) a distinction will be made between those privacy cases in which the defamatory character of the falsehood is reasonably apparent on its face and those cases in which the defamatory character of the statement is not so reasonably apparent.

Unfortunately, both of these approaches fail to consider adequately the difficulty of detecting or determining damages for mental suffering. Gertz erected two media protections, a requirement of fault on the part of the publisher and a requirement that actual damages be pleaded and proved. Although these approaches comport with the requirement of fault, they give inadequate weight to the actual injury stricture, which is the primary safeguard against self-censorship.

An approach which establishes harm to reputation as a prerequisite to recovery for mental suffering in all defamation cases brought by non-public figures does not suffer from this shortcoming. For this reason, the use of such an approach appears to hold the most promise for achieving a proper balance of the competing interests. It considers both the degree of defendant's fault and the possibility of self-censorship in those cases where the actual injury requirement cannot be effectively met. Moreover, it is more theoretically compatible with the differences between defamation and privacy. Because of these features, this approach provides the most suitable framework for use by the Court when a privacy action brought by a non-public figure coines before it. 